\title{
Sustained Expression of Negative Regulators of Myelination Protects Schwann Cells from Dysmyelination in a Charcot-Marie-Tooth 1B Mouse Model
}

\author{
Francesca Florio, ${ }^{1}$ Cinzia Ferri, ${ }^{1}$ Cristina Scapin, ${ }^{1}{ }^{\oplus}$ M. Laura Feltri, ${ }^{2,3,4} \mathbb{C}^{\circ}$ Lawrence Wrabetz, ${ }^{2,3,4}$ \\ and $\mathbb{D}^{\text {Maurizio D’Antonio }}{ }^{1}$ \\ ${ }^{1}$ Division of Genetics and Cell Biology, San Raffaele Scientific Institute, DIBIT, Milan, Italy 20132, ${ }^{2}$ Hunter James Kelly Research Institute, ${ }^{3}$ Department of \\ Biochemistry, and ${ }^{4}$ Department of Neurology, Jacobs School of Medicine and Biomedical Sciences, University at Buffalo, Buffalo, New York 14203
}

Schwann cell differentiation and myelination in the PNS are the result of fine-tuning of positive and negative transcriptional regulators. As myelination starts, negative regulators are downregulated, whereas positive ones are upregulated. Fully differentiated Schwann cells maintain an extraordinary plasticity and can transdifferentiate into "repair" Schwann cells after nerve injury. Reactivation of negative regulators of myelination is essential to generate repair Schwann cells. Negative regulators have also been implicated in demyelinating neuropathies, although their role in disease remains elusive. Here, we used a mouse model of Charcot-Marie-Tooth neuropathy type 1B (CMT1B), the P0S63del mouse characterized by ER stress and the activation of the unfolded protein response, to show that adult Schwann cells are in a partial differentiation state because they overexpress transcription factors that are normally expressed only before myelination. We provide evidence that two of these factors, Sox2 and Id2, act as negative regulators of myelination in vivo. However, their sustained expression in neuropathy is protective because ablation of Sox 2 or/and Id2 from S63del mice of both sexes results in worsening of the dysmyelinating phenotype. This is accompanied by increased levels of mutant P0 expression and exacerbation of ER stress, suggesting that limited differentiation may represent a novel adaptive mechanism through which Schwann cells counter the toxic effect of a mutant terminal differentiation protein.

Key words: Charcot-Marie-Tooth; Id2; myelin; Schwann cell; Sox2; UPR

Significance Statement

In many neuropathies, Schwann cells express high levels of early differentiation genes, but the significance of these altered expression remained unclear. Because many of these factors may act as negative regulators of myelination, it was suggested that their misexpression could contribute to dysmyelination. Here, we show that the transcription factors Sox 2 and Id 2 act as negative regulators of myelination in vivo, but that their sustained expression in Charcot-Marie-Tooth type 1B (CMT1B) represents an adaptive response activated by the Schwann cells to reduce mutant protein toxicity and prevent demyelination.

\section{Introduction}

Myelin formation in the PNS requires the ensheathment of axons and their wrapping by Schwann cells plasma membrane. Schwann cells derive from the neural crest and each step in their develop-

Received Jan. 23, 2018; revised March 2, 2018; accepted March 16, 2018.

Author contributions: F.F. wrote the first draft of the paper; M.L.F. and M.D. edited the paper; L.W. and M.D. designed research; F.F., F.C., C.S., and M.D. performed research; M.L.F., L.W., F.F., and M.D. analyzed data; M.D. wrote the paper.

This work was supported by Fondazione Telethon, Italy (Grant GGP14147 to M.D.), the Italian Ministry of Health (Grant GR-2011-02346791 to M.D.), and the European Community (FP7/2007-1013 under Grant Agreement HEALTH-F2-2008-201535 to L.W. and M.L.F.). We thank Antonio lavarone for Id $2^{-1-}$ mice, Robin Lovell-Badge for Sox ${ }^{\mathrm{F} / \mathrm{F}}$ mice, Carla Taveggia and Silvia Nicolis for lentiviral constructs, Desirée Zambroni and Maria Carla Panzeri at the Alembic imaging facilityof San Raffaele Scientific Institute for excellent technical assistance, and David B. Parkinson for proofreading the manuscript.

The authors declare no competing financial interests. ment is tightly controlled by complex transcriptional networks (Svaren and Meijer, 2008; Stolt and Wegner, 2016). Schwann cell specification initiates with the expression of the transcription factor Sox10, which promotes migration and activates signals fundamental for differentiation and myelination such as ErbB3, Oct6, and Krox20 (Topilko et al., 1994; Jaegle et al., 1996; Britsch et al., 2001; Ghislain et al., 2003; Prasad et al., 2011). The timely onset of myelination requires an accurate balance between these positive signals and negative regulators (Jessen and Mirsky, 2008; Stolt and Wegner, 2016). Among the latter are c-Jun, a transcrip-

Correspondence should be addressed to Maurizio D'Antonio, San Raffaele Scientific Institute, via Olgettina 58 Milan, Italy 20132. E-mail: dantonio.maurizio@hsr.it.

DOI:10.1523/JNEUROSCI.0201-18.2018

Copyright $\odot 2018$ the authors $\quad 0270-6474 / 18 / 384275-14 \$ 15.00 / 0$ 
tion factor shown to cross-antagonize Krox20-induced myelin gene expression in vitro and ex vivo (Parkinson et al., 2008); Sox2, the overexpression of which drastically reduces myelination ex vivo and in vivo (Le et al., 2005; Roberts et al., 2017); and Notch, the inactivation of which promotes myelination in vivo (Woodhoo et al., 2009). Other factors such as Krox24/Egr 1 and Id 2 have also been proposed to act as negative regulators of myelination, although direct evidence is missing (Jessen and Mirsky, 2008; Mager et al., 2008). All of these factors are normally expressed in premyelinating Schwann cells and are then downregulated concomitantly to the initiation of myelination (Jessen and Mirsky, 2008).

Fully differentiated Schwann cells maintain a remarkable plasticity and, after nerve injury, are capable to trans-differentiate to a distinct repair cell phenotype that drives nerve regeneration (Arthur-Farraj et al., 2012). A crucial step in this process is the reexpression of c-Jun, which is necessary for myelin breakdown and subsequent remyelination (Parkinson et al., 2008; ArthurFarraj et al., 2012; Gomez-Sanchez et al., 2015). Importantly, other factors such as Sox 2 and Id 2 are also upregulated after nerve damage (D'Antonio et al., 2006; Parkinson et al., 2008), which is suggestive of a role in the regeneration process. These observations also suggest that misregulated expression of these factors may be potentially involved in inefficient or failed myelination and remyelination, a condition often encountered in peripheral neuropathies.

The most common neuropathies are caused by alterations in genes encoding structural myelin proteins such as PMP22 duplication, which is associated with Charcot-Marie-Tooth type 1A (CMT1A) (Valentijn et al., 1992), or MPZ mutations associated with CMT1B (Warner et al., 1996). For example, the S63del mutation in MPZ (P0S63del) causes CMT1B in humans and a similar dysmyelinating neuropathy in mice (Wrabetz et al., 2006; Miller et al., 2012). The mechanism underling the pathology is the retention of the mutant protein in the ER activating an unfolded protein response (UPR) (Pennuto et al., 2008; D'Antonio et al., 2013), a complex set of signaling pathways aimed at restoring ER homeostasis (Walter and Ron, 2011).

Transcriptomic analysis showed that adult P0S63del nerves maintain the expression of factors characteristic of premyelinating and promyelinating Schwann cells such as Sox2, Sox4, Id2, c-Jun, and Oct6 (D’Antonio et al., 2013). A similar signature was also observed in another CMT1B model, the P0R98C mouse, and in some models of PMP22-related neuropathies (GiamboniniBrugnoli et al., 2005; Saporta et al., 2012; Fledrich et al., 2014). The significance of the increase of these factors is not clear, but it has been postulated that their misexpression may contribute to dysmyelination (Patzkó et al., 2012; Fledrich et al., 2014), although recent work has shown that the activation of c-Jun is actually neuroprotective in a mouse model of CMT1A (Hantke et al., 2014).

Here, we provide evidence that Sox 2 and Id 2 are negative regulators of myelination in vivo, but also show that their genetic ablation in the hypomyelinating S63del neuropathic mouse model significantly worsens the pathology within the nerve. Our observations suggest a mechanism in which the sustained expression of early differentiation factors limits Schwann cells maturation and protects them by the deleterious effects of an excessive expression of toxic P0 mutant protein.

\section{Materials and Methods}

Mice. All experiments involving animals were performed in accordance with experimental protocols approved by the San Raffaele Scientific In- stitute Animal Care and Use Committee and the Italian Ministry of Health. P0S63del transgenic mice (Wrabetz et al., 2006), P0-Cre mice (Feltri et al., 1999), Id $2^{-1-}$ mice (Yokota et al., 1999), and Sox2 floxed $\left(\right.$ Sox $2^{\mathrm{F} / \mathrm{F}}$ ) mice (Taranova et al., 2006) and their genotyping procedures have been described previously. To generate mice carrying the specific ablation of Sox 2 in Schwann cells, Sox ${ }^{\mathrm{F} / \mathrm{F}}$ mice were crossed with P0Cre mice. The resulting P0Cre/Sox $2^{\mathrm{F} /+}$ mice were backcrossed with Sox $2^{\mathrm{F} /+}$ to obtain P0Cre/Sox $2^{\mathrm{F} / \mathrm{F}}$ mice (Sox $2^{\mathrm{SCKO}}$ ). The P0Cre/Sox $2^{\mathrm{F} / \mathrm{F}}$ mice were also crossed with Id $2^{+/-}$mice to obtain the P0Cre/Sox $2^{\mathrm{F} /+} / \mathrm{Id} 2^{+/-}$ animals, which were than backcrossed with $\operatorname{Sox} 2^{\mathrm{F} /+} / \mathrm{Id} 2^{+/-}$mice to produce the experimental Sox $2^{\mathrm{SCKO}} / \mathrm{Id} 2^{-1-}$ mice and relative controls. Finally, to produce the S63del/Sox $2^{\mathrm{SCKO}} / \mathrm{Id} 2^{-1-}$ and control mice, $\mathrm{P} 0 \mathrm{Cre} / \mathrm{Sox} 2^{\mathrm{F} /+} / \mathrm{Id} 2^{+/-}$mice were crossed with S63del mice to obtain the S63del/P0Cre/Sox $2^{\mathrm{F} /+} / \mathrm{Id} 2^{+/-}$mice, which were backcrossed with the P0Cre/Sox $2^{\mathrm{F} /+} / \mathrm{Id} 2^{+/-}$mice.

P0S63del mice were maintained on the FVB/N background, P0Cre and Id 2 mice were on the C57BL/6-N background, and the Sox 2 floxed mice were on the129/SvPas background. When possible, we have used WT littermates as control. Alternatively, we used P0Cre, Sox $2^{\mathrm{F} /+}$ or Sox $2{ }^{\mathrm{F} / \mathrm{F}}$ littermates that do not show evidence of alteration in PNS myelin (data not shown) as controls. Male and female mice were used equally because we have no evidence of sex influence upon animal phenotype.

Morphological analysis. For morphological analysis, sciatic nerves were dissected at the indicated time points, immediately fixed in $2 \%$ glutaraldehyde, and processed as described previously (Occhi et al., 2005). Semithin section images were acquired with a Leica DM5000B microscope and TEM images were acquired using a LEO 912AB Transmission Electron Microscope (Zeiss). G-ratio analysis on P3 nerves was performed on electron microscopy images using ImageJ software. More than 50 myelinated fibers from 15-20 images per animal were analyzed from at least three mice per genotype. G-ratio analysis on P21 and P28 semithin sciatic nerve sections was instead performed using a semiautomated computerbased morphometry (Leica Q-Win) as described previously (D'Antonio et al., 2013). Six to 10 microscopic fields from nerves of three to four mice per genotype were analyzed.

$R N A$ isolation, $q R T-P C R$, and allelic discrimination assay. For qRTPCR assays, total RNA was isolated from sciatic nerves pulverized in liquid nitrogen using TRIzol reagent (Invitrogen) according to the manufacturer's instructions. One microgram of total RNA was reverse transcribed to cDNA using the Superscript III kit (Invitrogen) following the manufacturer's instructions. qRT-PCR (TaqMan; Applied Biosystems) was performed on an ABI PRISM 7700 Sequence Detector (Applied Biosystems). The following assays on demand (Applied Biosystems) were used: Oct6 (Mm00843534_s1), Krox20/Egr2 (Mm00456650_m1), Id2 (Mm00711781_m1), c-jun (Mm00495062_s1), Sox2 (Mm00488369_ m1), Sox4 (Mm00486320_s1), P0tot (Mm00485141_g1), CHOP/DDIT3 (Hs01090850_m1), Bip/HSPA5 (Hs99999174_m1), XBP1s (Mm03464496_ m1), and 18S (Hs99999901_s1) as an internal control. For the allelic discrimination assay, $400 \mathrm{ng}$ of total RNA was reverse transcribed and two different assays on demand were used: one specific for the WT transcript of P0 (AIGJRL0) and the other specific for the S63del mutant transcript (AIHSPR8) synthesized as FAM-MGB test (Applied Biosystems). We created a titration curve mixing different concentration of the plasmids expressing the two isoforms and the results were used to evaluate the ratio between the two transcripts in mouse sciatic nerves.

Lentiviruses preparation and DRG and Schwann cell transduction. The Id 2 transcript was amplified from cDNA obtained from reverse-transcribed mouse sciatic nerve total RNA and directionally cloned in the SpeI and XhoI sites of the pLenti6/V5 vector (Invitrogen). The pL6V5EGFP lentivirus was used as a control. The lentiviral vectors pLVIP-Sox2 and pLVIP-EGFP were provided by Prof. Silvia Nicolis. pLVIP is a bicistronic plasmid containing an additional IRES at the $5^{\prime}$ of the Sox 2 cDNA that allows the simultaneous expression of Sox 2 and EGFP, which is used as transduction efficiency marker. For the lentiviral preparation, 293T cells were transiently transfected with the packaging vectors pMDLg/ PRRE and CMV R8.74 (Follenzi et al., 2002) as described previously (Dull et al., 1998). Lentivirus particles were purified through ultracentrifugation and used for Schwann cell and DRG infection experiments. 
Primary rat Schwann cells were purified from P3 rat sciatic nerve and cultured as described previously (Feltri et al., 1992). Schwann cell transduction efficiency, assessed by counting GFP or anti-V5 positive cells $3 \mathrm{~d}$ after infection, was $\sim 60 \%$. Infected Schwann cells were then trypsinized and seeded on purified DRG neurons at the concentration of 200,000 cells/sample. Five days after seeding, myelination was induced by adding ascorbic acid (AA) (Sigma-Aldrich) for $15 \mathrm{~d}$, after which the cocultures were fixed and immunostaining performed.

Myelinating DRG explant cultures and DRG/Schwann cell cocultures. DRGs were isolated from E13.5 mouse embryos and plated on $13 \mathrm{~mm}$ coverslips coated with rat type I collagen (Cultrex). For organotypic explants, one DRG was plated in each well in C medium (MEM, $2 \mathrm{mM}$ L-glutamine; Invitrogen), 10\% FBS, $4 \mathrm{mg} / \mathrm{ml}$ D-glucose (Sigma-Aldrich), and $50 \mathrm{ng} / \mathrm{ml} \mathrm{NGF} \mathrm{(Harlan} \mathrm{Laboratories)} \mathrm{supplemented} \mathrm{with} 100 \mathrm{U} / \mathrm{ml}$ penicillin and $100 \mu \mathrm{g} / \mathrm{ml}$ streptomycin (Invitrogen). The following day, the medium was changed to Neurobasal (NB) medium (4 g/L D-glucose, $2 \mathrm{~mm}$ L-glutamine, $50 \mathrm{ng} / \mathrm{ml} \mathrm{NGF}$, and B27; Invitrogen) for $4 \mathrm{~d}$. For lentiviral infection, purified viral particles were diluted in $\mathrm{C}$ medium and infection was confirmed via EGFP or V5 staining. Four days after infection, DRGs were treated with C medium supplemented with $50 \mu \mathrm{g} / \mathrm{ml}$ AA to induce myelination. The medium was changed every $2 \mathrm{~d}$ for $15 \mathrm{~d}$.

For DRG/Schwann cell cocultures, after dissection, DRGs were dissociated by incubation with trypsin followed by mechanical homogenization and plated at the concentration of $1.5 \mathrm{DRG} /$ well on 48 -well plate plastic dishes (Corning) coated with rat type I collagen. Neurons were purified via three treatments with NB medium supplemented with $10 \mu \mathrm{M}$ 5-fluoro-2' -deoxyuridine and $10 \mu \mathrm{m}$ uridine (Sigma-Aldrich) alternated with nonsupplemented NB to eliminate dividing Schwann cells and fibroblasts from the culture. DRG neurons were then seeded with 200,000 infected or noninfected rat Schwann cells (see above) per well. Five days after seeding, AA was added to the fresh $\mathrm{C}$ medium to induce myelination. Treatment was continued for $15 \mathrm{~d}$, after which the cocultures were fixed in $4 \%$ PFA and subjected to immunofluorescence analysis to evaluate the number of MBP-positive internodes per culture. Images were automatically acquired at $10 \times$ magnification using the IN Cell Analyzer 1000 (GE Lifesciences). Images were then enlarged to full screen with Image $\mathrm{J}$ and $\mathrm{MBP}$-positive segments included between two node gaps in 10 fields per well were counted.

Protein extraction and Western blotting. Sciatic nerves were dissected and immediately frozen in liquid nitrogen. Frozen nerves were homogenized in a stainless steel mortar at $-80^{\circ} \mathrm{C}$ and then transferred to nerve lysis buffer (95 mm NaCl, 25 mm Tris-HCl, pH 7.4, 10 mm EDTA, 2\% SDS) supplemented with protease (Sigma-Aldrich) and phosphatase $\left(\mathrm{Na}_{3} \mathrm{VO}_{4}\right.$ and NaF; Sigma-Aldrich) inhibitors. Protein extraction was performed as described previously (Wrabetz et al., 2000). Protein concentration was determined with the BCA assay (Pierce) and equal amounts of protein per sample were used to perform SDS-PAGE analysis: $20-30 \mu \mathrm{g}$ for intracellular proteins and $5-10 \mu \mathrm{g}$ for myelin proteins. For Western blotting, after transfer onto PVDF membrane, incubation of the membrane with primary antibodies was performed in 3\% nonfat milk in TBS with $0.05 \%$ Tween 20 (Sigma-Aldrich) using the following reagents: rabbit anti-calnexin (1:1000; Sigma-Aldrich, C4731, RRID: AB_476845), rabbit anti-Krox20 (1:500; Covance, PRB-236P, RRID: AB_10064079), goat anti-Oct6 (1:500; Santa Cruz Biotechnology, sc11661, RRID:AB_2268536), rabbit anti-Id2 (1:200; Abcam, ab85990, RRID:AB_2041767), rabbit anti-Sox2 (1:1000; Santa Cruz Biotechnology, sc-20088, RRID:AB_2255358), goat anti-Sox4 (1:200; Santa Cruz Biotechnology, sc-17326, RRID:AB_2196083), rabbit anti-c-Jun (1:1000; Cell Signaling Technology, 9165, RRID:AB_2130165), rabbit anti-c-Jun Phospho(S63) II (1:1000; Cell Signaling Technology, 9261, RRID: AB_2130159), mouse anti-tubulin (1:2000; Sigma-Aldrich, T4026, RRID:AB_477577), 1:1 mix of mouse anti-MBP SMI94 (1:1000; Covance, SMI-94R-100, RRID:AB_510039), and SMI99 (1:1000; Covance, SMI-99, RRID:AB_2314772), to detect all of the MBP isoforms. Appropriate secondary antibodies (anti-mouse HRP, DAKO, P0260, RRID: AB_2636929; anti-goat HRP, Thermo Fisher Scientific, A16005, RRID: AB_2534679; anti-rabbit HRP, DAKO, P0448, RRID:AB_2617138) were diluted at 1:5000 in 5\% milk $1 \times$ TBS $0.05 \%$ Tween 20 and results were
Table 1. Level of expression of early transcription factor in S63del nerves at different time points after birth

\begin{tabular}{lccc}
\hline Gene & $5 \mathrm{~d}$ & $28 \mathrm{~d}$ & $4 \mathrm{mo}$ \\
\hline Sox2 & 1.6 & 2.9 & 1.6 \\
Id2 & 1.75 & 2 & 1.75 \\
C-Jun & 1.4 & 1.6 & 1.2 \\
Sox4 & 1.2 & 2 & 1.3 \\
Oct6/Pou3f1 & 1.2 & 2.9 & 2 \\
Krox20 & 1 & 1.3 & 1.3 \\
Scap & -1.5 & -1.5 & -1.3 \\
Srebf2 & -1.55 & -1.4 & -1.5 \\
\hline
\end{tabular}

Microarray analysis of $\$ 63$ del nerves shows sustained expression of dedifferentiation genes. Expression levels are expressed as fold change compared with WT control of early Schwann cell transcription factors in S63del sciatic nerves at 5 d, $28 \mathrm{~d}$, and 4 months after birth (D'Antonio et al., 2013).

visualized using GE Healthcare ECL or ECL Prime chemiluminescent reagent and autoradiography film.

Immunofluorescence. Sciatic nerves were dissected from mice at P21 and fixed for $30 \mathrm{~min}$ in 4\% PFA (Sigma-Aldrich), embedded in OCT (Bio Optica), and frozen in liquid nitrogen. Then, $10-\mu \mathrm{m}$-thick cryosections were fixed for $10 \mathrm{~min}$ in $4 \%$ PFA, rinsed, and permeabilized for $5 \mathrm{~min}$ in $0.2 \%$ Triton X-100 (Sigma-Aldrich), PBS $1 \times$ (Invitrogen). Sections were blocked in ADS buffer $(0.1 \%$ lysine dihydrochloride, $0.02 \%$ sodium azide and $1 \times$ PBS) supplemented with $10 \%$ bovine serum albumin and $0.1 \%$ Triton X-100 for $30 \mathrm{~min}$. The following primary antibodies were diluted in ADS buffer with $0.1 \%$ Triton X-100 and incubated overnight: rat anti-MBP (1:10 culture medium of hybridoma cells, gift from Judit Grinspan), rabbit anti-Sox2 (1:200; Santa Cruz Biotechnology, sc-20088, RRID:AB_2255358) or rabbit anti-Id2 (1:50; Abcam, ab85990, RRID: AB_2041767). Secondary conjugated antibodies were as follows: anti-rat FITC (1:300; Jackson ImmunoResearch, 712-095-153, RRID: AB_2340652) for MBP and anti-rabbit TRITC (1:300; Jackson ImmunoResearch, 711-025-152, RRID:AB_2340588) for Id2 and Sox2. Nuclei were visualized with Hoechst (1:10000; Sigma-Aldrich). Samples were mounted using VectaShield (Vector Laboratories) and images were acquired with a Leica TCS SP8 SMD FILM confocal microscope. DRG immunofluorescence was performed as described previously (D'Antonio et al., 2013) using rat Hybridoma anti-MBP (1:10) and chicken antineurofilament M (1:500; BioLegend, 822701, RRID:AB_2564860). MBP staining was visualized using an anti-rat 549-conjugated (1:1000; Jackson ImmunoResearch, 112-506-062) and neurofilament with anti-chicken Cy5-conjugated (1:200; Abcam, ab97147, RRID:AB_10679551) secondary antibodies and nuclei identified by Hoechst staining.

Experimental design and statistical analysis. For all experiments, $n=$ 3-5 unless otherwise stated. Experiments were not randomized, but data collection and analysis were performed blinded to the conditions of the experiments. Researchers blinded to conditions or genotype performed morphological and morphometric analyses. No statistical methods were used the predetermine sample size, but our sample sizes are similar to those generally used in the field. All the experiments were analyzed by Student's $t$ test or one-way ANOVA with Tukey post hoc test correction. A value of $p \leq 0.05$ was considered significant. Graphs represent mean \pm 1 SEM.

\section{Results}

CMT1B Schwann cells present an altered differentiation state Transcriptomic analysis revealed that adult Schwann cells in sciatic nerves of S63del mice, a model of CMT1B, maintain the expression of transcription factors normally expressed only in premyelinating Schwann cells (D'Antonio et al., 2013). We detected a significant increase in the expression of known or putative negative regulators of myelination such as c-Jun, Sox2, and Id 2 (Jessen and Mirsky, 2008) in S63del nerves at all of the examined time points (Table 1). Sox4, a transcription factor shown recently to participate in peripheral myelination (Bartesaghi et al., 2015), and Oct6, a crucial factor required for the transition from promyelinating to myelinating Schwann cells (Jaegle et al., 


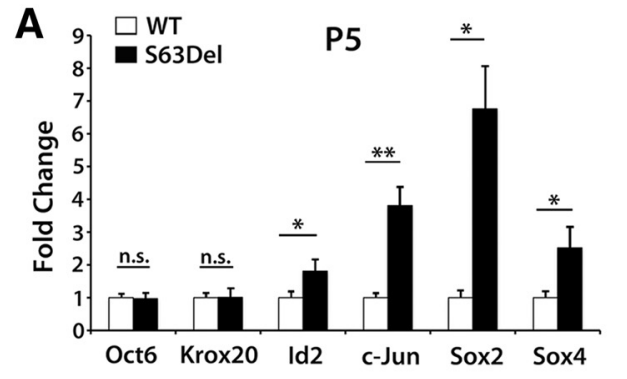

B

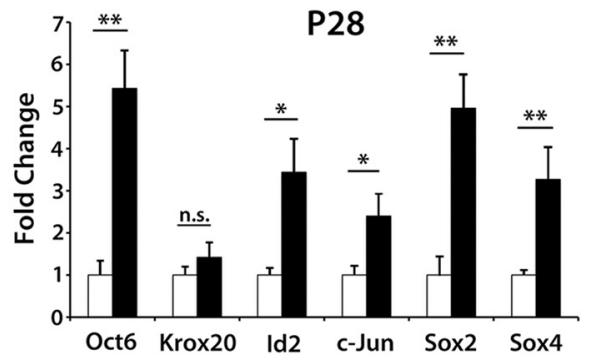

C

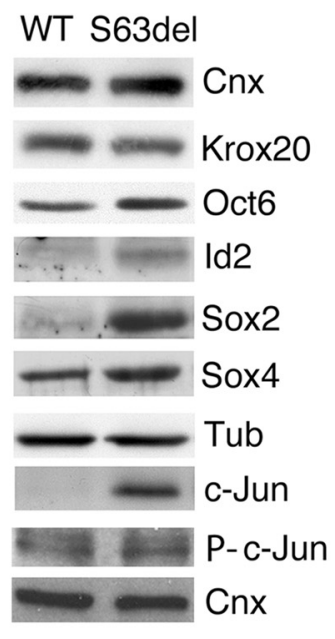

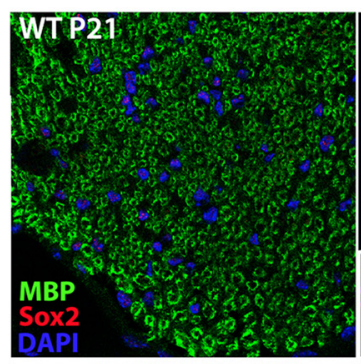
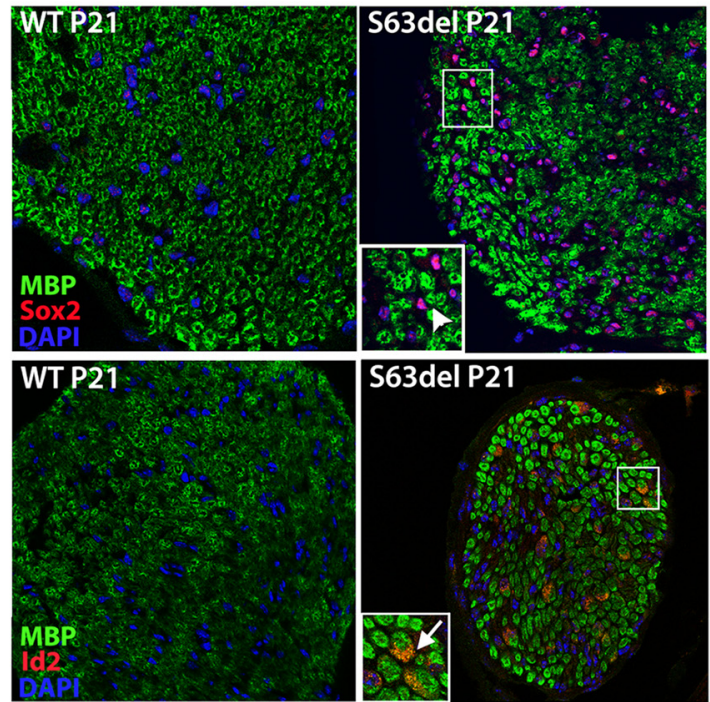

Figure 1. S63del nerves showing altered differentiation state. A, qRT-PCR analysis on P5 (top) and P28 (bottom) S63del and WT sciatic nerves to validate some of the early Schwann cell differentiation factors. S63del values are expressed as fold change compared with WT. Error bars indicate SEM; $n=3-5$ RT from independent pools of nerves. ${ }^{*} p<0.05$, ** $p<0.01$ by Student's $t$ test. $\boldsymbol{B}$, Western blot analysis on P28 sciatic nerve lysates. Tubulin (Tub) and Calnexin (Cnx) were used as loading controls. C, Immunohistochemistry (IHC) on cryosections of P21 S63del and WT sciatic nerves. Sections $10 \mu \mathrm{m}$ thick were stained with anti-Sox2 or anti-Id2 antibodies (red), anti-MBP antibody (green) for myelin, and DAPI (blue) for cell nuclei. In S63del nerves, Sox2 localizes in Schwann cell nuclei (arrowhead in the top inset), whereas Id2 appears to accumulate in the cytoplasm (arrow in the bottom inset).

1996), showed similar increases, whereas Krox20, a pivotal regulator of myelination (Topilko et al., 1994; Parkinson et al., 2004), appeared unaffected (Table 1). Conversely, the expression of Scap and Srebf2, two transcription factors essential for the timely upregulation of genes involved in cholesterol and fatty acid synthesis (Verheijen et al., 2009), was decreased.

qRT-PCR analysis on mouse sciatic nerves confirmed that the expression of c-Jun, Sox2, and Id2 were significantly higher in S63del compared with control animals (WT) at both P5 and P28 (Fig. 1A). We then tested whether this was true also at the protein level. Western blot analysis performed on protein extracts from WT and S63del sciatic nerves at P28 confirmed the increase of c-Jun, Sox2, and Id 2 proteins, as well as Oct6 and Sox4, in the neuropathic model (Fig. $1 B$ ).

Finally, we evaluated the localization of Sox 2 and Id 2 by immunostaining on P28 sciatic nerve cryosections. As expected, they were clearly detected in adult nerves in S63del mice but not in WT littermates. In particular, Sox 2 showed a Schwann cells nuclear localization, whereas Id2 appeared to localize in the Schwann cell cytoplasm (Fig. 1C). Overall, these data indicate that S63del Schwann cells present an altered differentiation state characterized by the sustained expression of a series of early transcription factors. We hypothesized that this could interfere with normal myelination and contribute to the hypomyelinating phenotype.

\section{Sox2 exerts a Schwann cell-autonomous negative effect on myelination}

A negative role for Sox 2 in myelination had been already proposed after both in vitro and ex vivo experiments (Le et al., 2005; Parkinson et al., 2008) and, more recently, in in vivo overexpression studies (Roberts et al., 2017). Conversely, very little is known about the role of Id 2 in myelination in the PNS (Jessen and Mirsky, 2008). To further support the negative role of Sox2 during PNS myelination and to clarify the function of Id2, we infected DRG explants from WT mice with lentiviral constructs express- ing Sox2, Id2, or GFP. We observed that the expression of Sox2 significantly impaired myelination efficiency, as confirmed by the reduction in MBP-positive internodes. Conversely, Id2 does not appear to have significant effects on DRG myelination (Fig. $2 A$ ). A caveat in the experiment is that lentiviruses are able to transduce both Schwann cells and neurons. To determine the cell-autonomous effect of Sox 2 and to evaluate the effect of the Schwann-cell-specific overexpression of Id2, we purified neurons from WT DRGs and cocultured them with primary rat Schwann cells previously infected with either Sox 2 or Id 2 lentivirus. Again, we observed a negative effect of Sox 2 expression on myelination to an extent similar to that described after whole DRG explant infection, suggesting a Schwann-cell-specific effect of Sox2. As before, Id 2 expression did not alter myelination (Fig. 2B). To confirm that the observed inhibition of myelination is due to the expression of Sox 2 in Schwann cells, we performed the converse experiment, infecting purified WT DRGs neurons with Sox2expressing lentiviruses and coculturing them with primary rat Schwann cells. In this case, we did not observe any alteration in myelination, suggesting that neuronal overexpression of Sox 2 has no effect (data not shown). Together, these data confirm that Sox2 overexpression has a Schwann-cell-specific negative role on myelination, whereas Id 2 overexpression does not appear to affect myelination, at least ex vivo.

\section{Ablation of Schwann cell Sox 2 and Id 2 promotes myelination in vivo}

The overexpression studies outlined above supported the role of Sox 2 as a negative regulator of myelination. To further substantiate Sox2 role in Schwann cell development, we performed in vivo loss-of-function experiments. We generated a Schwann-cellspecific Sox 2 knock-out mouse (Sox ${ }^{\text {SCKO }}$ ) by crossing Sox 2 floxed mice (Taranova et al., 2006) with P0Cre mice (Feltri et al., 1999). Sox 2 is normally expressed in immature Schwann cells and is then suppressed during the active phase of myelination (Jessen and Mirsky, 2005). We analyzed mice at P3, when myeli- 

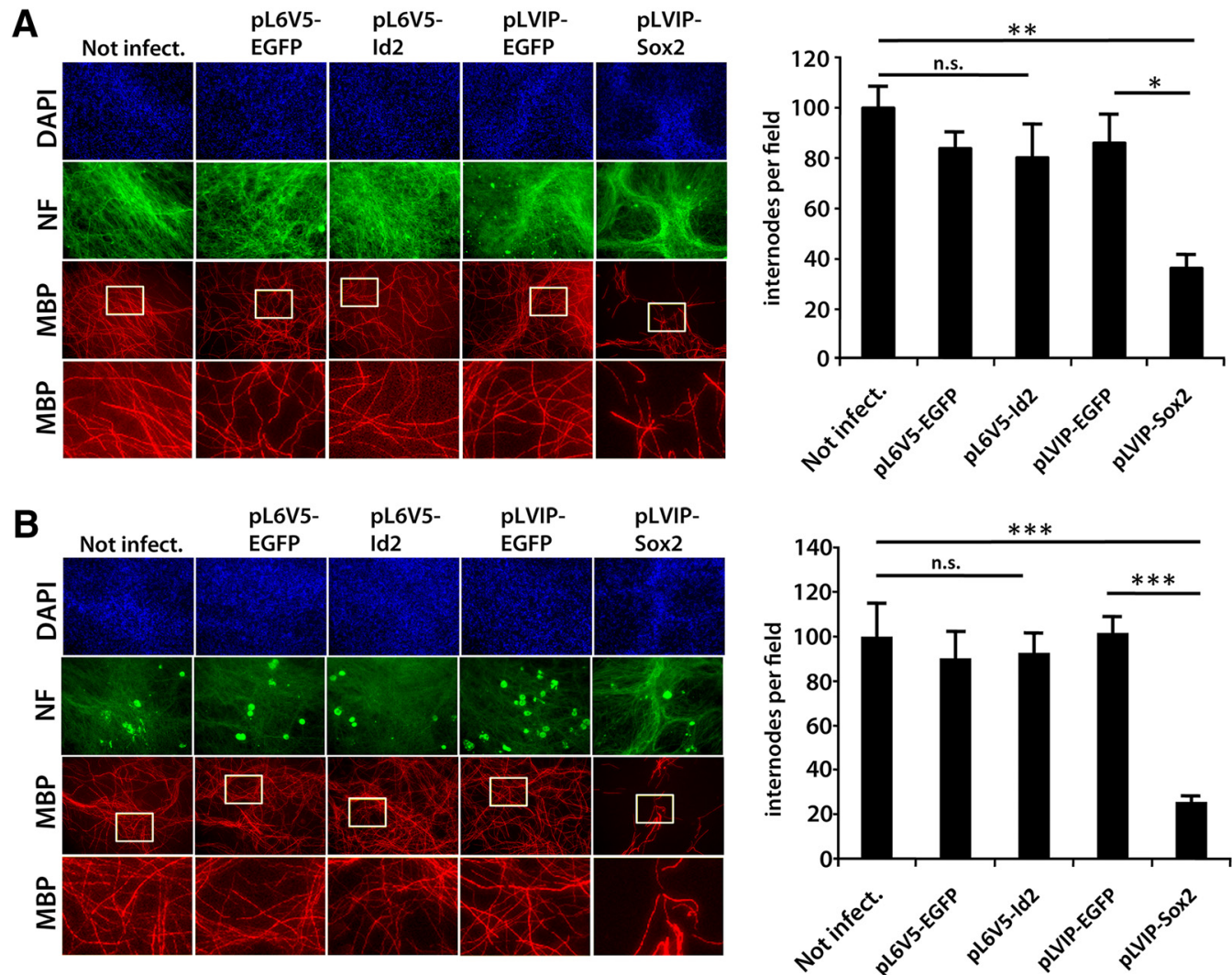

Figure 2. Sox2 overexpression impairs myelination in DRG cultures. $A$, Immunofluorescence and quantification of MBP-positive internodes in DRG explants infected with Id2- or Sox2-expressing lentiviruses. Myelin is stained with anti-MBP (red), neurons with anti-NF-M (green), and cell nuclei with DAPI (blue). Bottom MBP panels represent the magnifications (3.8 $\times$ ) of the inset. EGFP-expressing lentiviruses were used as a control. Sox2-overexpressing DRGs are significantly less myelinated compared with both noninfected and EGFP-infected DRGs $\left(F_{(4,15)}=6,295, p=\right.$ 0.0035). B, Purified WT DRG neurons were seeded with Id2- or Soxz-overexpressing Schwann cells. The quantification of MBP-positive internodes confirmed that Sox2 overexpression impairs myelination in a Schwann-cell-autonomous way compared with noninfected and EGFP-infected Schwann cells $\left(F_{(4,18)}=11,02, p=0.0001\right)$ by one-way ANOVA followed by Tukey post hoc analysis. Number of internodes per field was normalized to the WT. Data are shown as means \pm SEM of four independent experiments. ${ }^{*} p<0.05,{ }^{* *} p<0.01$ and ${ }^{* *^{*}} p<0.001$.

nation is beginning and Sox2 is still expressed in WT mouse peripheral nerves. By morphological analysis on sciatic nerve transverse sections, Sox ${ }^{\text {SCKO }}$ nerves appeared slightly more myelinated compared with WT controls. Indeed, g-ratio analysis showed a trend toward lower values in P3 Sox ${ }^{\text {SCKO }}$ nerves (Fig. $3 B)\left(\right.$ Sox $2{ }^{\text {SCKO }} 0.7435 \pm 0.0129$; control $0.7649 \pm 0.0126 ; p=$ $0.1457)$, suggesting a mild hypermyelination.

Similar analysis was also performed in P3 Id2-null mice, in which the Id 2 gene is ablated in all tissues (Yokota et al., 1999). Id2-null sciatic nerves resembled what was observed in the Sox $2^{\text {SCKO }}$ model (Fig. $3 C$ ). In particular, g-ratio analysis on EM sections showed a significant increase in myelin thickness in Id2null nerves (Fig. 3D) $\left(\mathrm{Id} 2^{-/-} 0.7355 \pm 0.0063\right.$; control $0.7662 \pm$ 0.0048 ; $p=0.0185)$. Moreover, in Id2-null nerves, we also detected a trend toward increased number in myelinated fibers compared with WT controls among those axons that were already in a 1:1 relationship with a Schwann cell (average 70.6\% in Id2-null vs $58.65 \%$ in control; $p=0.1714$ ).

Based on these observations, we generated double mutant mice (Sox $2^{\mathrm{SCKO}} / \mathrm{Id} 2^{-/-}$) to evaluate whether the ablation of both proteins would have an additive effect on myelination. P3 sciatic nerves (Fig. 3E) showed an increase in the number of myelinated fibers $\left(70.38 \%\right.$ in Sox $2^{\mathrm{SCKO} / \mathrm{Id} 2^{-1-}}$ vs $54.72 \%$ in control $p=0.0769$ ) and a significantly lower g-ratio (Fig. $3 F$ ) $\left(\right.$ Sox $2^{\mathrm{SCKO}} / \mathrm{Id} 2^{-/-} 0.7213 \pm 0.0127$; control $0.7740 \pm 0.0051$; $p=0.0077)$. Together, these data indicate that the ablation of Sox2, Id2, or both causes hypermyelination during early phases of peripheral nerve development, suggesting that they are indeed negative regulators of myelination in vivo.

We next evaluated whether the hypermyelination persisted in older mice. To this aim, we analyzed sciatic nerves of Sox $2^{\text {SCKO }}$ and Id $2^{-1-}$ mice at P28 and P21, respectively (most Id2-null mice died perinatally and none survived after P21). By this stage, the nerves appeared indistinguishable from the controls (Fig. $4 A, B)$, as confirmed by g-ratio analysis (Sox $2^{\text {SCKO }} 0.6307 \pm$ 0.011 vs control $0.6356 \pm 0.012$, n.s.; Id $2^{-/-} 0.6473 \pm 0.013$ vs control $0.6565 \pm 0.027$ n.s.), indicating that the hypermyelination observed in $\mathrm{P} 3$ nerves is a transitory phenotype. Intriguingly, in the Sox $2^{\mathrm{SCKO}} / \mathrm{Id} 2^{-1-}$ nerves at $\mathrm{P} 21$, despite overall normal myelin thickness, we observed frequent polyaxonal myelination of bundles containing several unsorted axons with diameter $>1$ $\mu \mathrm{m}$ and in which axons were not separated by Schwann cell cytoplasmic protrusions (Fig. 4D). This phenotype is also seen in many mutants in which there may be premature differentiation of Schwann cells and precocious myelination (for review, see Feltri et al., 2016), suggesting that concomitant ablation of Sox2 and Id 2 leads to early Schwann cell cycle exit and differentiation.

\section{Id2-induced hypermyelination is likely a Schwann-cell-} autonomous effect

In Sox $2^{\text {SCKO }}$ mice, the mild increase in myelin thickness is most probably due to the specific ablation of Sox 2 in Schwann cell. Conversely, in the Id2-null mice, it is not possible to determine cell autonomy and the observed phenotype may be also due to 

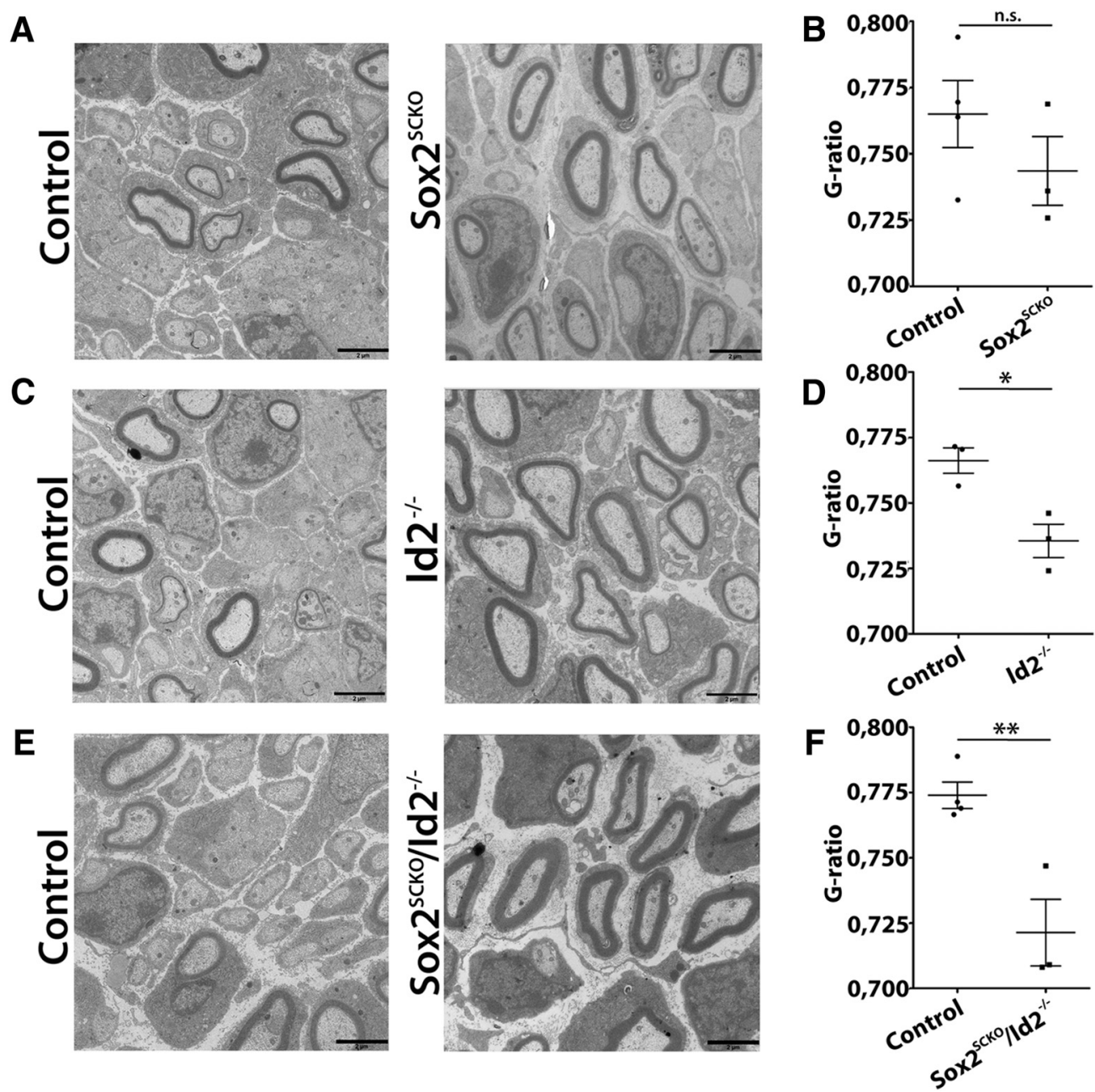

Figure 3. Ablation of Sox2 and Id 2 results in hypermyelination in $\mathrm{P} 3$ sciatic nerves. $A, C, E$, TEM images of $\mathrm{P} 3$ control and Sox2 ${ }^{\mathrm{SCK} 0}, \mathrm{Id} 2^{-I-}$ and Sox $2^{\mathrm{SCKO}} / \mathrm{dd} 2^{-I-}$ sciatic nerves. All transgenic mice show signs of hypermyelination compared with controls. $\boldsymbol{B}, \boldsymbol{D}, \boldsymbol{F}$, g-ratio evaluation of myelin thickness in control and Sox $2^{\mathrm{SCK} 0}$, Id $2^{-1-}$ and Sox $2^{\mathrm{SCKO}} / \mathrm{Id} 2^{-I-}$ P 3 mice. Sox $2^{\mathrm{SCKO}}$ mice show a trend toward thicker myelin, whereas Id $2^{-I-}$ and Sox $2^{\mathrm{SCK} 0} / \mathrm{Id} 2^{-I-}$ mice are significantly hypermyelinated $\left({ }^{*} p=0.0185 \mathrm{and}^{* *} p=0.0077\right.$ respectively, by Student's $t$ test) compared with the control. Scale bars, $2 \mu \mathrm{m}$.

lack of Id2 in other cells. To begin to evaluate this, we first cultured DRG explants from WT and Id2-null embryos and looked at myelination at different time points. Intriguingly, after $5 \mathrm{~d}$ of myelination, Id $2^{-1-}$ DRGs have a significantly higher number of myelinated internodes compared with WT DRGs (Fig. 5A). This difference is reduced as myelination progresses and is no longer significant after 8 or $15 \mathrm{~d}$ of myelination (data not shown). This result parallels what seen in vivo and indicates that the ablation of Id 2 in Schwann cells or neurons causes early and transient hypermyelination. To evaluate whether this phenotype is due to Schwann cell or neurons, we purified DRG neurons from WT and Id2-null mice and cultured them together with WT primary rat Schwann cells. We allowed myelination to proceed for different time points $(5,7,12$, and $16 \mathrm{~d})$, but we never observed any significant difference (Fig. $5 B$ and data not shown). Together, these data suggest that the phenotype observed in P3 mice and in day 5 DRG explants is most likely due to the lack of Id2 in Schwann cells rather than neurons.

\section{Ablation of Sox 2 and Id 2 in neuropathic mice worsens the phenotype}

Our ex vivo and in vivo data corroborate and expand previous observations indicating that Sox 2 has a negative role in Schwann cell myelination (Le et al., 2005; Parkinson et al., 2008; Roberts et al., 2017). Moreover, we showed for the first time that Id 2 also exerts a negative role in developmental myelination in vivo. This led us to hypothesize that, in S63del CMT1B nerves, their sustained expression could interfere with myelination, contributing to the hypomyelination. To test this hypothesis, we first ablated Sox2 in Schwann cells of S63del mice. Morphological analysis performed at P28 showed that peripheral nerves of S63del/ Sox $2^{\text {SCKO }}$ were actually more severely affected than S63del nerves (Fig. 6A). The g-ratio in S63del/Sox $2^{\mathrm{SCKO}}$ was increased compared with S63del nerves $(0.72 \pm 0.01$ vs $0.70 \pm 0.01, p=$ 0.0097), indicating more hypomyelination (Fig. 6B). Accordingly, there was also a significant increase in the percentage of amyelinated fibers within the nerve (Fig. 6C) and Western blotting assay showed a reduction of MBP in S63del/Sox $2{ }^{\mathrm{SCKO}}$ nerves (Fig. 6D,E) compared with S63del, confirming the worsening of the phenotype. These results suggest a protective role for Sox2 expression in neuropathy.

We next evaluated the effect of Id2 ablation on S63del neuropathy by crossing Id $2^{-1-}$ and S63del mice. By P21, the S63del/Id2 ${ }^{-1-}$ mice showed an exacerbation of the neuropathic phenotype similar to what was observed after ablation of Sox2 (Fig. 7A). Indeed, g-ratio analysis confirmed a more pronounced 
A
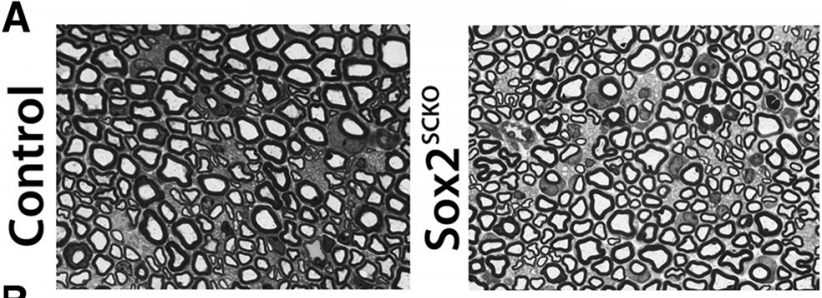

B

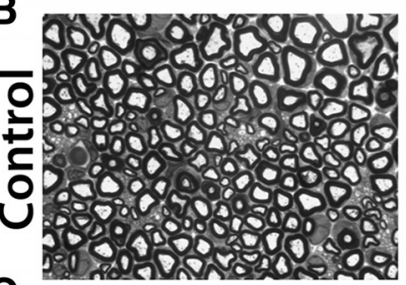

C

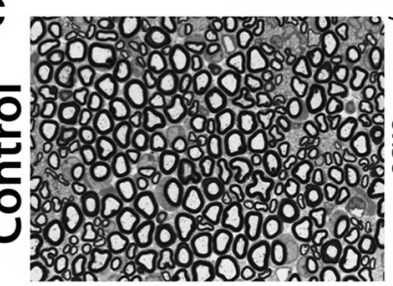

D
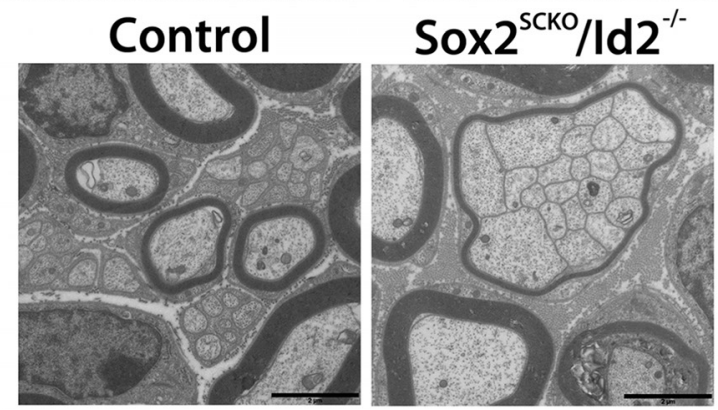

Figure 4. Sox2- and Id2-null nerves are normally myelinated at later time points. $\boldsymbol{A}-\boldsymbol{C}$, Semithin section of P 28 Sox $2^{\mathrm{SCK} 0}$ and $\mathrm{P} 21 \mathrm{Id} 2^{-1-}$ and Sox $2^{\mathrm{SCKO}} / \mathrm{Id} 2^{-1-}$ sciatic nerves. In all transgenic mice, the extent of myelination is comparable to the control. $D$, TEM images of P21 control and Sox $2^{\mathrm{SCKO}} / \mathrm{dd} 2^{-/-}$nerves. In the double-knock-out transgenic mice, we frequently found Remak bundles containing large ( $>2 \mu \mathrm{m}$ in diameter) unsorted axons and surrounded by a thin myelin sheath, which were never seen in control nerves. Scale bars, $2 \mu \mathrm{m}$.

hypomyelination in the S63del/Id $2^{-1-}$ mouse $(0.75 \pm 0.01)$ with respect to the $\mathrm{S} 63 \mathrm{del}(0.72 \pm 0.015 ; p=0.042)$ (Fig. $7 B)$. Finally, the percentage of amyelinated fibers was significantly increased in P21 S63del/Id2 ${ }^{-1-}$ sciatic nerves (Fig. 7C) and Western blot analysis showed a reduced amount of $\mathrm{MBP}$ (Fig. $7 \mathrm{D}, E$ ) compared with S63del.

The ablation of either Sox 2 or Id 2 from S63del mice led to a comparable worsening of the neuropathic phenotype. In S63del mice, the pathology is associated with the activation of a UPR due to the retention of mutant P0S63del in the ER (Wrabetz et al., 2006). Therefore, we tested whether the worsening of the phenotype after Sox 2 or Id 2 ablation in S63del nerves was accompanied by an increase in ER stress. Using qRT-PCR, we measured the mRNA expression of the UPR target genes BiP, CHOP, and spliced Xbp1. However, in both S63del/Sox $2^{\text {SCKO }}$ and S63del/ Id $2^{-1-}$ nerves, we detected only a nonsignificant trend toward an increase of these ER stress markers compared with S63del nerves (data not shown). We thus wondered whether, like in development, the ablation of both transcription factors could have a synergistic effect in the neuropathy, allowing us to better determine the underlying molecular mechanism. To test this, we generated S63del/Sox $2^{\mathrm{SCKO}} / \mathrm{Id} 2^{-1-}$ mice and analyzed sciatic nerve morphology at P21. Indeed, morphological analysis by semithin section clearly showed that the combined loss of Sox 2 and Id 2 led to a dramatic worsening of the phenotype with respect to the S63del mice (Fig. 8A), with a remarkable reduction in the number of myelinated fibers. EM images confirmed this observation, showing axons with caliber larger than $1 \mu \mathrm{m}$ completely amyelinated or significantly hypomyelinated (Fig. $8 B$ ). Moreover, we often noticed the presence of myelin debris in Schwann cell cytoplasm, suggesting ongoing demyelination (Fig. $8 B$ ). This result further supports the idea that, in the S63del neuropathic model, the sustained expression of both Sox 2 and Id 2 is largely protective. Importantly, the ablation of one protein exacerbates the phenotype, but not as drastically as the ablation of both, suggesting a synergistic effect.

\section{Sox 2 and Id 2 sustained expression limits mutant P0S63del toxicity}

The negative role on myelination of Sox 2 and Id 2 suggests that their downregulation at the start of myelination is necessary to properly activate the Schwann cell differentiation program and myelin genes expression. We speculated that the Sox 2 and Id2 protective effect in neuropathic nerves was likely due to their ability to maintain Schwann cells in a limited differentiation state. The S63del phenotype is in fact dose dependent: mice that express higher levels of P0S63del protein have higher ER stress levels and a more severe dysmyelinating phenotype (Wrabetz et al., 2006). We thus evaluated the mRNA expression of P0 in sciatic nerves of S63del and S63del/Sox $2^{\mathrm{SCKO}} / \mathrm{Id} 2^{-1-}$ mice. In agreement with our hypothesis, we observed an increased expression of total P0 transcript in S63del sciatic nerves after Sox2 and Id2 ablation (Fig. 9A). Because the S63del transgene is under the control of the whole P0 gene (Feltri et al., 1999), the mRNA for both WT and mutant P0 should be equally increased. To test this, we performed a quantitative allelic discrimination assay to evaluate the relative amounts of the two transcripts. As shown in Figure $9 B$, the ratio between the two mRNAs remains constant in S63del and S63del/Sox $2^{\mathrm{SCKO}} / \mathrm{Id} 2^{-1-}$ sciatic nerves, suggesting that both transcripts are likely equally increased in the absence of Sox 2 and Id2. To further confirm that Sox 2 and Id 2 ablation is associated with increased mutant P0S63del levels, we evaluated the expression of a series of UPR markers. As expected, we saw increased levels of $\mathrm{CHOP}$ and $\mathrm{BiP}$ expression and enhanced $\mathrm{Xbp} 1$ splicing in the S63del/Sox $2^{\mathrm{SCKO}} / \mathrm{Id} 2^{-1-}$ nerves compared with S63del (Fig. 9C), indicating an exacerbation of the UPR that correlates with the worsened phenotype.

Together, our data indicate that the sustained expression of Sox 2 and Id 2 in S63del CMT1B nerves is a necessary component in the homeostatic adaptation of Schwann cells in response to the production of a toxic protein.

\section{Discussion}

Negative regulators of myelination are emerging as important determinants of Schwann cell differentiation and of nerve repair after injury, whereas their role in disease is less well understood. Here, we showed that Sox 2 and Id 2 act as negative regulators of myelination in vivo, but that their sustained expression in neuropathy may represent an adaptive mechanism that protects Schwann cells from the toxicity of a misfolded myelin protein.

\section{Sox 2 and Id 2 negatively regulate myelination in vivo}

The evidence that Sox 2 acts as negative regulator of myelination mostly derived from overexpression studies. In vitro, Sox 2 antagonizes Krox-20 induced myelin gene expression and 
A
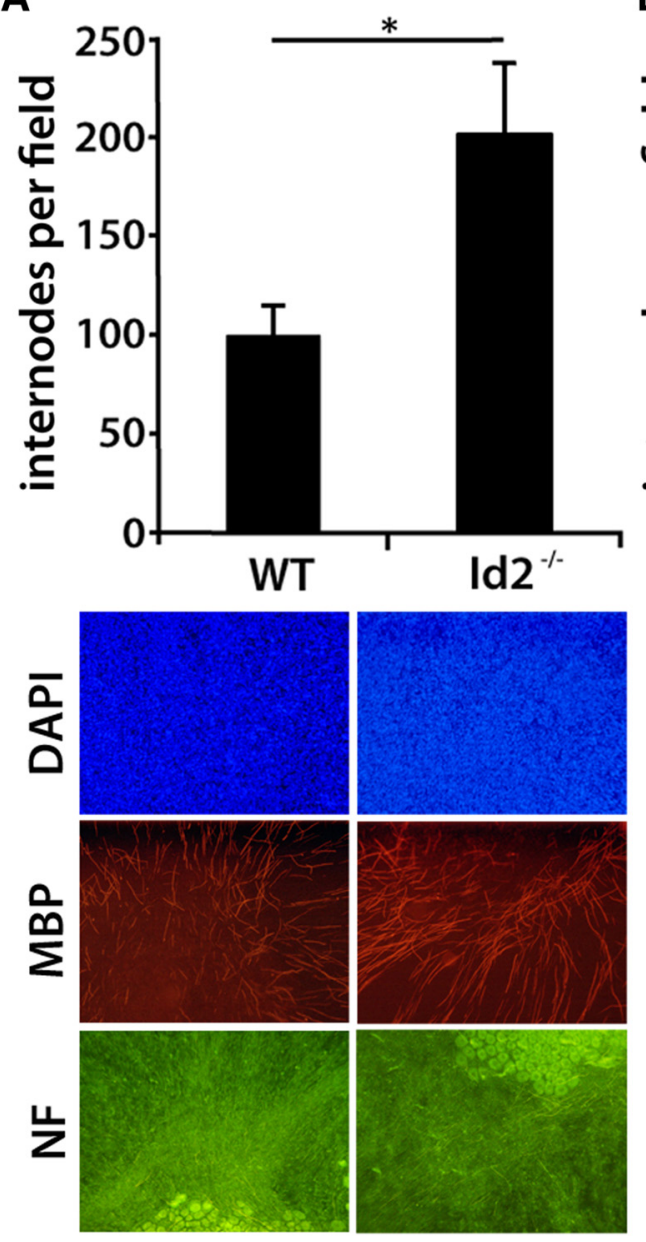

B
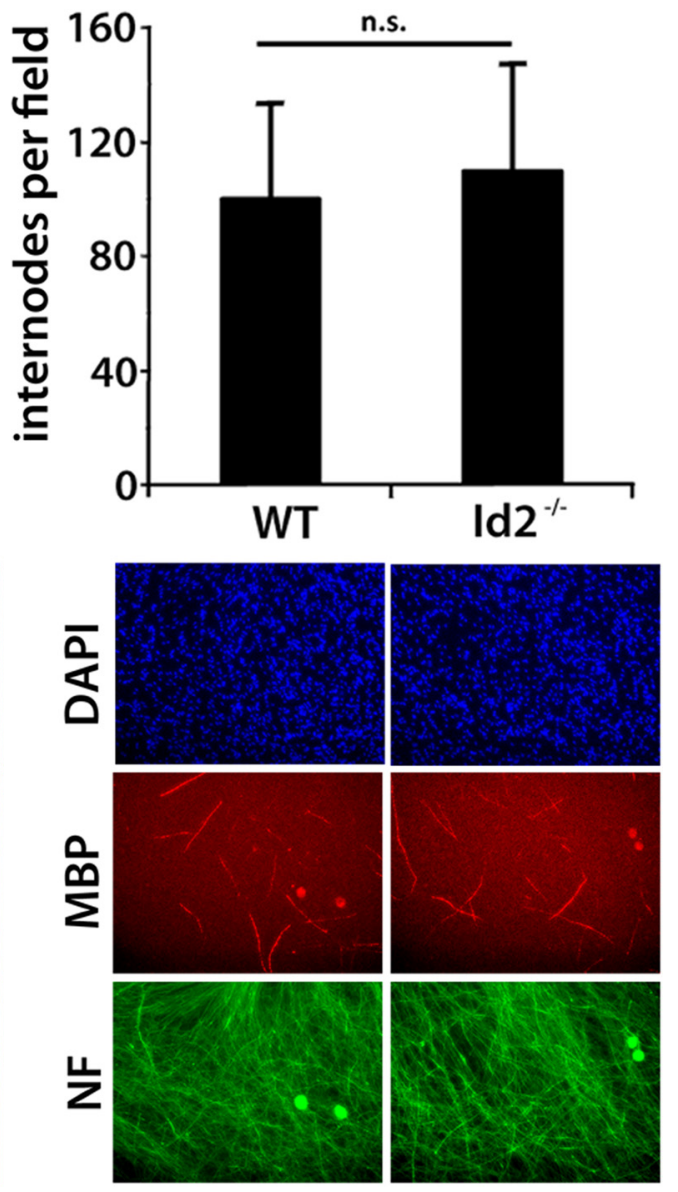

Figure 5. Id 2 negatively regulates myelination in a Schwann-cell-autonomous way. $\boldsymbol{A}$, Quantification of the number of myelinated axons and immunofluorescence in Id $2^{-1-}$ and WT DRG explants $5 \mathrm{~d}$ after the induction of myelination. Myelin is marked by anti-MBP (red), neurons by anti-NF M (green), and cell nuclei by DAPI (blue). Numbers of internodes per field are normalized to the control. Id $2^{-1-}$ DRGs show a significant increase in the number of myelinated fibers compared with the WT; $n=8$ embryos per genotype $\left({ }^{*} p=0.026\right.$ by Student's $t$ test). $\boldsymbol{B}, 0$ uantification of the number of myelinated internodes in WT and Id $2^{-1-}$ purified DRG neurons seeded with primary rat Schwann cells $7 \mathrm{~d}$ after the induction of myelination. Results represent the mean of three independent experiments.

enforced expression of Sox 2 in Schwann cells maintains them in an immature proliferative state (Roberts et al., 2017), preventing efficient myelination in DRG cocultures (Le et al., 2005). Importantly, recent in vivo studies showed that sustained Sox2 expression in Schwann cells blocks myelination and remyelination in peripheral nerves (Roberts et al., 2017).

Whereas it was well demonstrated that in the CNS Id2 negatively regulates oligodendrocyte differentiation (Chen et al., 2009; Chen et al., 2012), there were only some indications that Id 2 could act as negative regulator of PNS myelination. Id2 is downregulated by the Krox $20-\mathrm{NAB}$ complex during myelin progression (Mager et al., 2008) and is reexpressed after nerve injury (Le et al., 2005). Moreover, cAMP-induced P0 expression was increased by the repression of Id2 (Mager et al., 2008), suggesting that its reduction could be necessary for the activation of major myelin genes.

Our ex vivo experiments confirmed the negative role exerted by Sox 2 in myelination (Le et al., 2005) and showed that this effect is Schwann cell specific. Id2 overexpression in DRGs did not show any significant effect on myelination. However, Id2 does not work as a classical transcription factor but rather acts by binding other bHLH factors and blocking their activity (Yokota et al., 2001). To date, no Schwann-cell-specific Id2 interactor has been identified, but we cannot exclude that any Id2-specific effect on myelination would require the concomitant expression of other factors.

In vivo Schwann-cell-specific ablation of Sox 2 or full ablation of Id2 (most likely in a Schwann cell-autonomous manner) resulted in hypermyelination at P3. This effect was more evident in the double mutant, suggesting that the two factors act on different pathways and that their simultaneous ablation has a synergistic effect. However, the hypermyelination was transitory. This is probably due to the fact that both Sox 2 and Id2 are normally downregulated when myelination begins (Stewart et al., 1997; Le et al., 2005; Jessen and Mirsky, 2008), which will eventually even out the differences with the mutants. Nevertheless, in the doubleknock-out nerves, we often observed the myelination of bundles of yet unsorted axons by a single Schwann cell. This is a feature of many mutant nerves in which immature Schwann cells prematurely exit from the cell cycle, differentiate, and create polyaxonal myelination (Porrello et al., 2014; Feltri et al., 2016). This would fit with the role of Sox 2 and Id2 in cell cycle control. It has in fact been shown that the levels of Id2 correlate with Schwann cell proliferation in vitro (Stewart et al., 1997) and that Sox2 expression increases Schwann cell proliferation both in vitro and in vivo (Le et al., 2005; Roberts et al., 2017). 
A

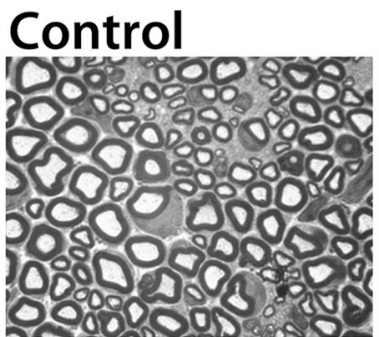

S63del

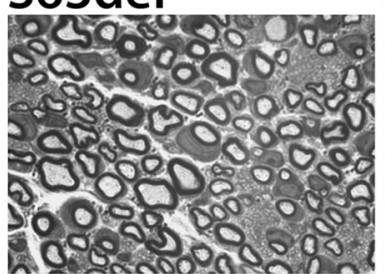

B

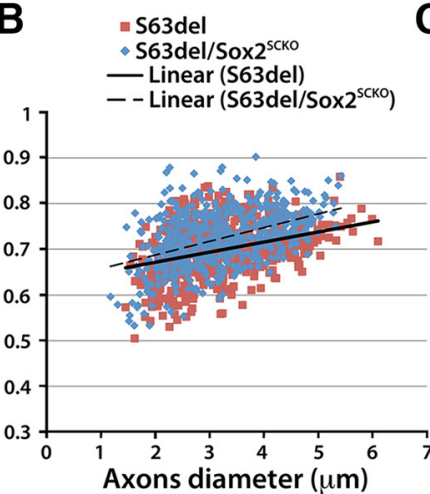

Sox $2^{\text {scko }}$

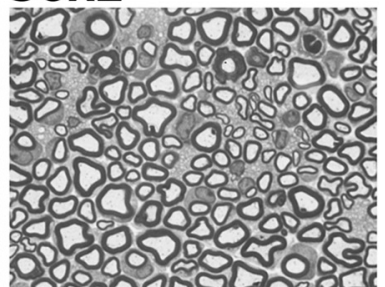

S63del/Sox2 $2^{\text {scko }}$
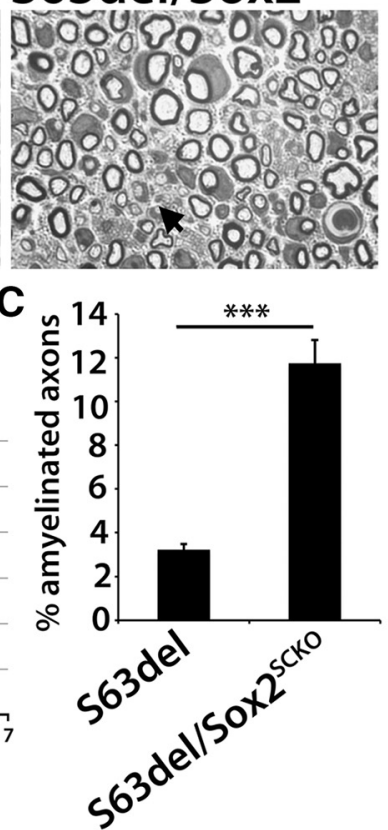

MBP protein levels A.U.
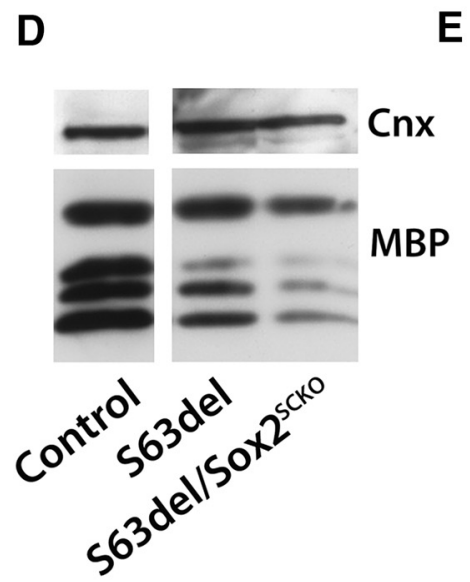

\section{A}

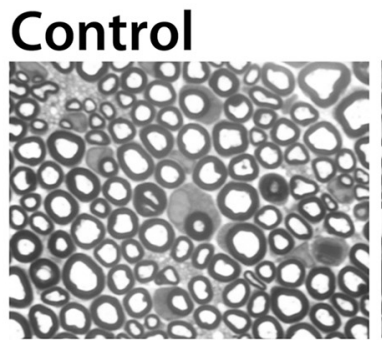

S63del

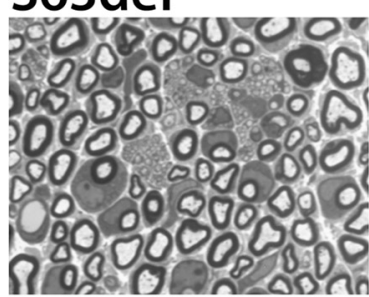

\section{B}
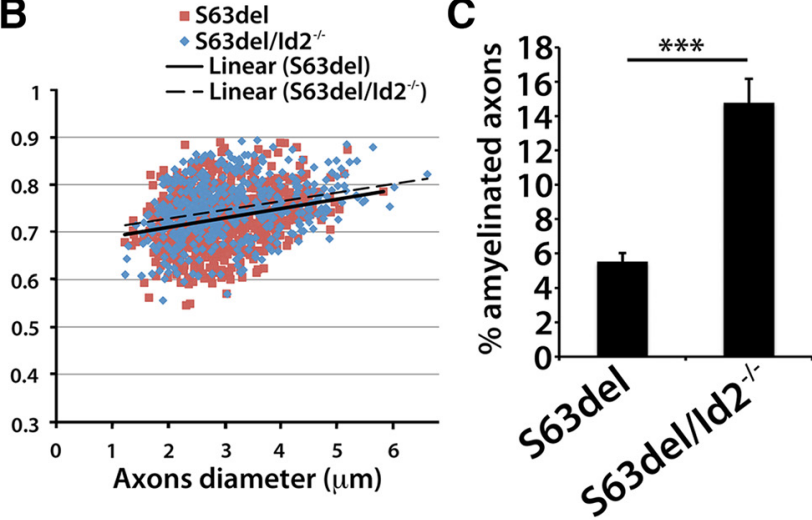

MBP protein levels A.U.
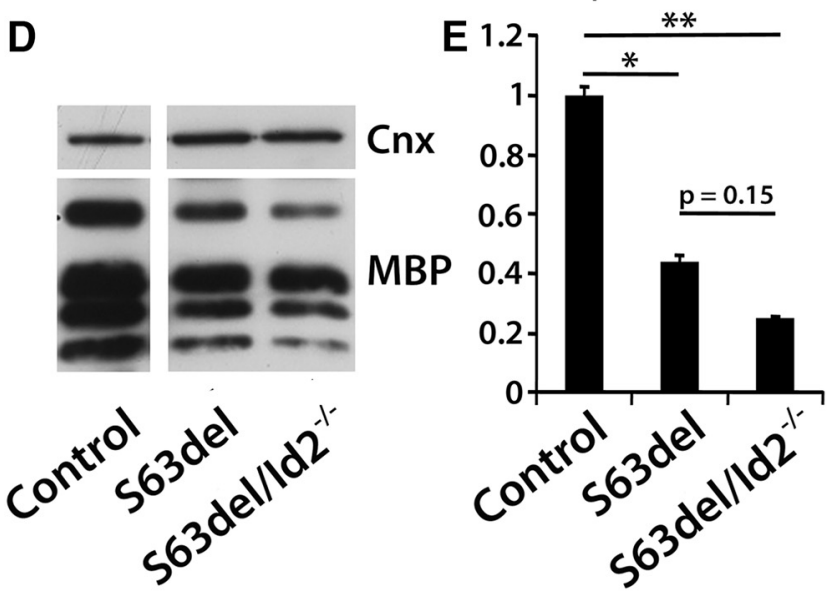

Figure 6. Ablation of Sox2 in S63del mice worsens the neuropathic mouse. $A$, Semithin sections of $\mathrm{P} 28$ sciatic nerves of the indicated genotypes. $\mathrm{S} 63 \mathrm{del} / \mathrm{Sox} 2^{\mathrm{SCKO}}$ nerves appear hypomyelinated compared with $563 \mathrm{del}$ and show an increase in amyelinated axons (arrow). $\boldsymbol{B}$, g-ratio plotted by axon diameter in S63del and S63del $/$ Sox ${ }^{\text {SCKO }}{ }^{\text {nerves; }} n=5-6$ microscopic fields per mouse were analyzed from 3 mice per genotype. $C$, Number of amyelinated fibers in semithin section from P28 S63del and S63del/Sox2 ${ }^{\mathrm{SCKO}}$ mice. Values are expressed as percentage of the axons with diameter $>1 \mu \mathrm{m}$. Error bars indicate SEM; $n=3-5$ microscopic fields per mouse were analyzed from 3 mice per genotype. ${ }^{* * *} p<0.001\left(9.83 \mathrm{e}^{-8}\right)$ by Student's $t$ test. $\boldsymbol{D}$, Western blot for MBP on P28 control, S63del, and S63del/Sox ${ }^{\mathrm{SCK} 0}$ sciatic nerve protein extract. Calnexin was used as a loading control. One representative blot of three is shown. $\boldsymbol{E}$, MBP levels as determined by densitometry; A.U., arbitrary units. ${ }^{*} p=0.039$ and $^{* *} p=0.0017$ by Student's $t$ test.

Figure 7. Id 2 ablation worsens the phenotype of $S 63$ del neuropathic nerves. $A$, Semithin sections of P21 WT, Id $2^{-1-}$, S63del, and S63del//d2 $2^{-1-}$ sciatic nerves. As with Sox2 ablation, lack of Id 2 in 563 del nerves results in further worsening of the hypomyelinating phenotype and AN increase in amyelinated axons (arrow). $\boldsymbol{B}, \mathrm{g}$-ratio plotted by axon diameter in S63del and $S 63 \mathrm{del} / / \mathrm{d} 2^{-1-}$ sciatic nerve; $n=5-6$ microscopic fields per mouse were analyzed from 3 mice per genotype. C, Number of amyelinated fibers in $563 \mathrm{del}$ and $\$ 63 \mathrm{del} / / \mathrm{d} 2^{-1-}$ sciatic nerve semithin sections. Values are expressed as a percentage of total number of axons with diameter $>1 \mu \mathrm{m}$. Error bars indicate SEM; $n=3-5$ microscopic fields per mouse were analyzed from 3 mice per genotype. ${ }^{* * *} p<0.001\left(5.37 \mathrm{e}^{-6}\right)$ by Student's $t$ test. $\boldsymbol{D}$, Anti-MBP Western blot on control, S63del, and S63del//dd ${ }^{-/-}$sciatic nerve protein extract. MBP was reduced in S63del compared with the control and further reduced in $563 \mathrm{del} / \mathrm{ld} 2^{-1-}$. Calnexin was used as a loading control. One representative blot of four is shown $E$, MBP levels as determined by densitometry; A.U., arbitrary units. ${ }^{*} p=0.014$ and ${ }^{* *} p=0.0024$ by Student's $t$ test. 
Before our study, Notch was the only example of transcription factor whose inactivation would accelerate myelination in vivo (Woodhoo et al., 2009). Our work shows that ablation of Sox 2 and Id 2 also results in peripheral nerve hypermyelination, indicating that they play an important role in timing the onset of myelination. Further studies will be required to explore in detail the molecular targets of Id 2 and Sox 2 and to establish when myelination begins in their absence.

\section{Sustained expression of Sox 2 and Id 2 is} protective in neuropathic nerves

Similar to other mouse models of peripheral neuropathy, S63del nerves are characterized by the sustained expression of several negative regulators of myelination. Here, we showed that ablation of Sox 2 and Id2 from S63del mice severely worsens the CMT1B neuropathy. In these mice, mutant P0S63del is retained in the ER of Schwann cells, where it activates a UPR (Wrabetz et al., 2006; Pennuto et al., 2008), an adaptive mechanism through which cells attempt to cope with the accumulation of misfolded protein and maintain proteostasis (Volpi et al., 2017). We had shown previously that the UPR in S63del is dose dependent: mice expressing higher levels of P0S63del show increased UPR activation and a more severe neuropathic phenotype (Wrabetz et al., 2006). Indeed, the severely impaired phenotype in S63del nerves lacking both Sox 2 and Id 2 was accompanied by a remarkable increase in UPR activation. Interestingly, in S63del/Sox $2^{\text {SCKO }}$ and in S63del/Id $2^{-1-}$ nerves, in which the phenotype is only marginally worsened compared with S63del, we did not detect a significant increase in ER stress, indicating that Schwann cells are probably still able to adapt when only one factor is ablated. It is difficult to determine what the resulting phenotype would be if, rather than being completely ablated, these factors were normalized to WT levels. However, by P28, the expression of most negative regulators is almost undetectable in WT nerves (Fig. $1 B, C$ ) and therefore, at least at the time points analyzed, full inactivation readjusts their levels close to the WT.

Our data suggest that, consistent with the negative role of Sox 2 and Id 2 on myelination, their concomitant ablation promotes myelin protein expression, including the mutant P0S63del, further intoxicating the system. We cannot exclude that the increased expression of the WT P0 gene also plays a role. WT P0 overexpression does not activate a UPR (Wrabetz et al., 2000; Pennuto et al., 2008), but P0S63del exerts a dominant-negative effect, causing the partial retention in the ER

A

B
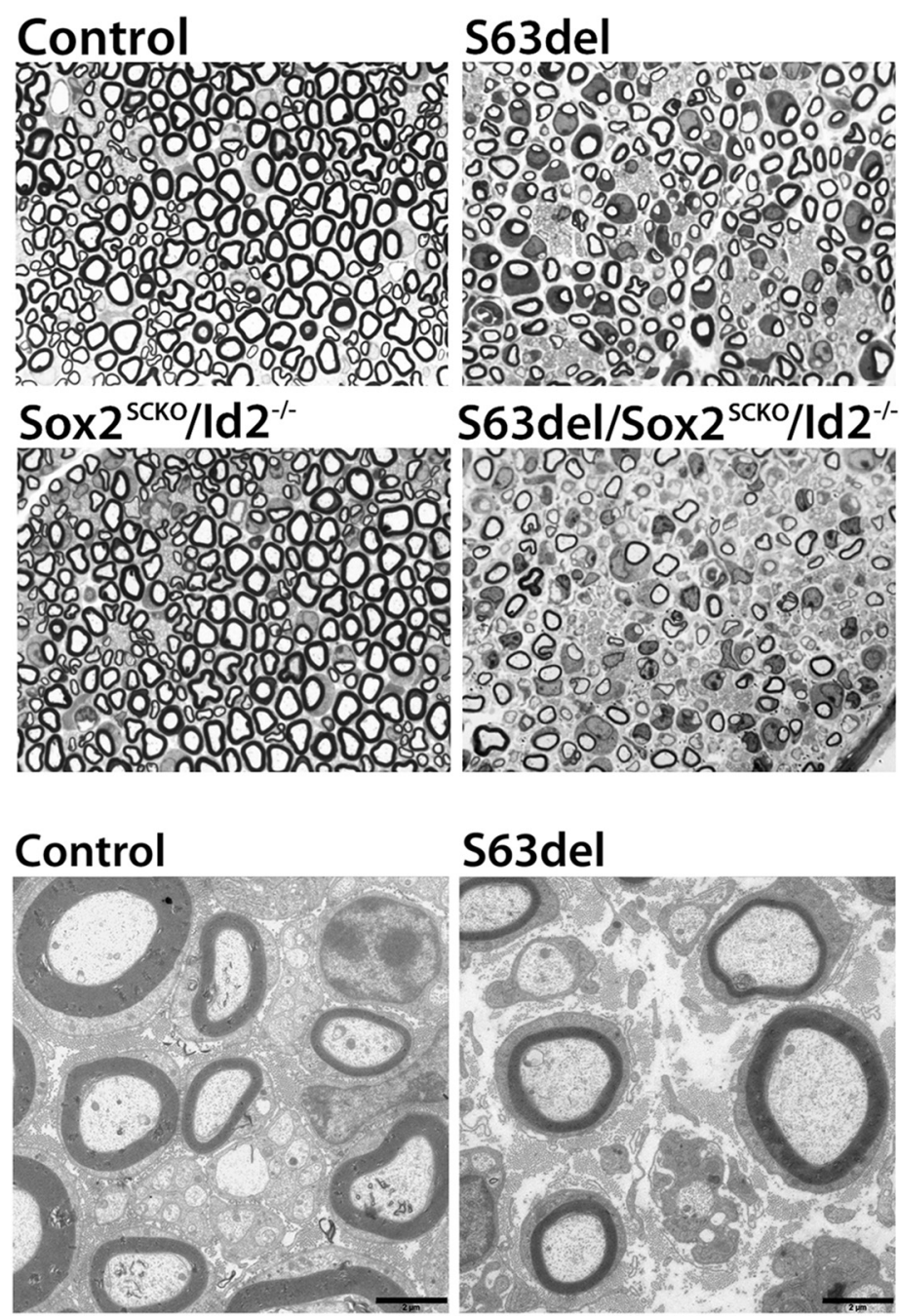

S63del
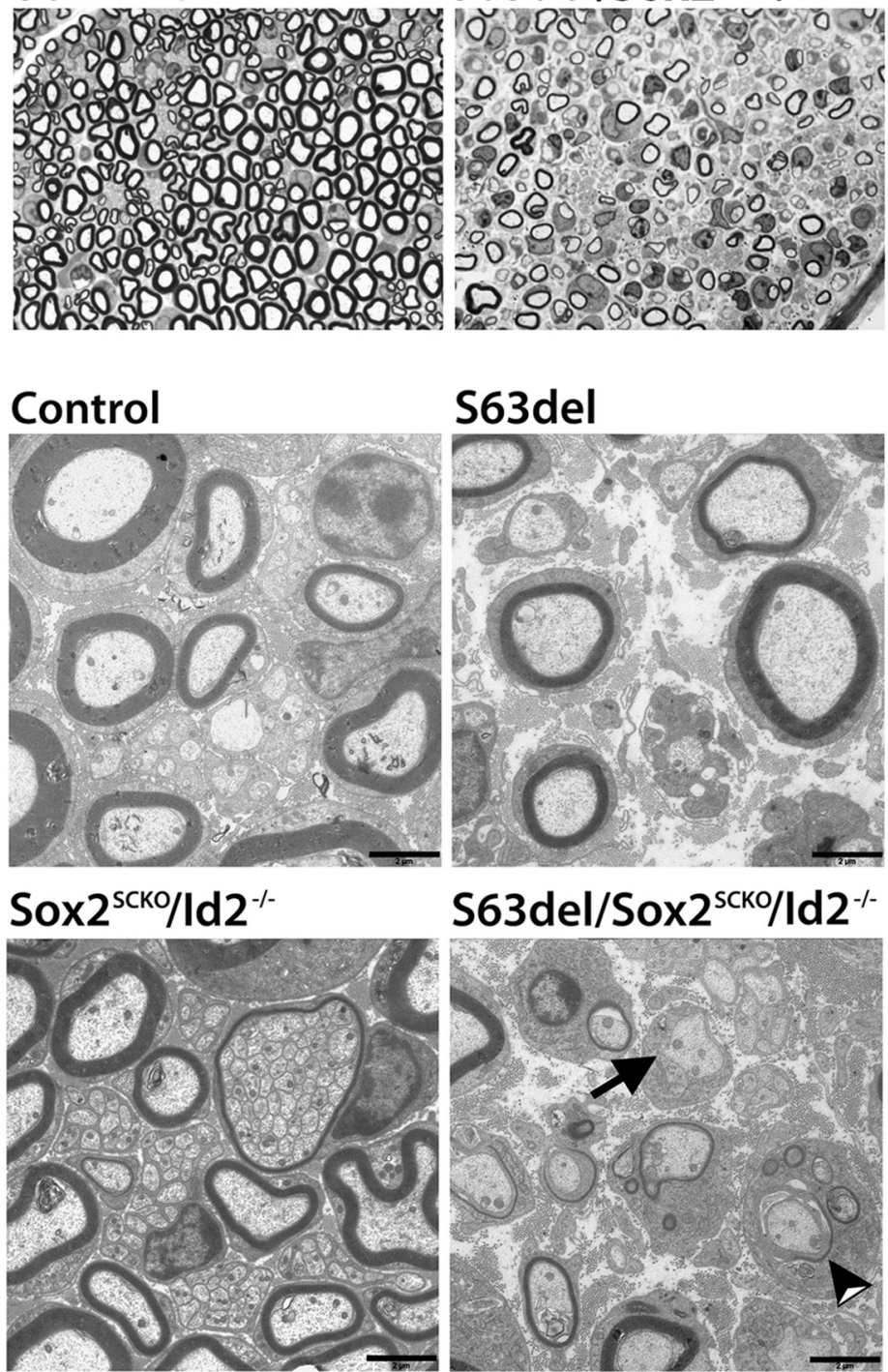

S63del/Sox $2^{\text {scko } / / d 2^{*}}$

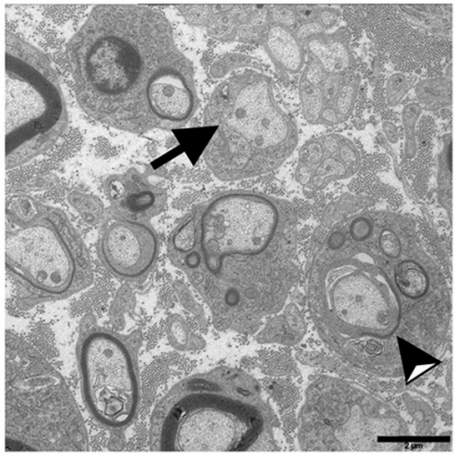

Figure 8. Ablation of both Sox 2 and Id 2 in S63del mouse causes a severe dysmyelinating phenotype. $A$, Semithin sections of P21 control, S63del, Sox $2^{\mathrm{SCKO}} / \mathrm{ld} 2^{-1-}$, and S63del/Sox2 $2^{\mathrm{SCKO}} / \mathrm{ld} 2^{-1-}$ nerves. Whereas control and Sox $2^{\mathrm{SCK} 0} / \mathrm{ld} 2^{-1-}$ nerves appear normally myelinated and S63del is hypomyelinated, in S63del, Sox2 $2^{\mathrm{SCKO}} / \mathrm{ld} 2^{-1-}$ nerve myelination is dramatically impaired. $\boldsymbol{B}$, TEM images confirming the hypomyelination in S63del nerves and the presence of myelinated Remak bundles in Sox2 $2^{\text {SCKO }}$ $\mathrm{Id} 2^{-1-}$ nerves. S63del/Sox2 $2^{\mathrm{SCK} 0} / \mathrm{ld} 2^{-1-}$ show dramatic hypomyelination with amyelinated axons (arrow) and ongoing demyelination (arrowhead). Scale bars, $2 \mu \mathrm{m}$.

and reduced delivery to myelin of WT P0 (Fratta et al., 2011), which may contribute to the pathology.

We conclude that the sustained expression of negative regulators of myelination represents a novel protective mechanism of homeostatic adaptation through which Schwann cells, by limiting their differentiation state, counter the toxic effect of mutant 


\section{A Potot mRNA}

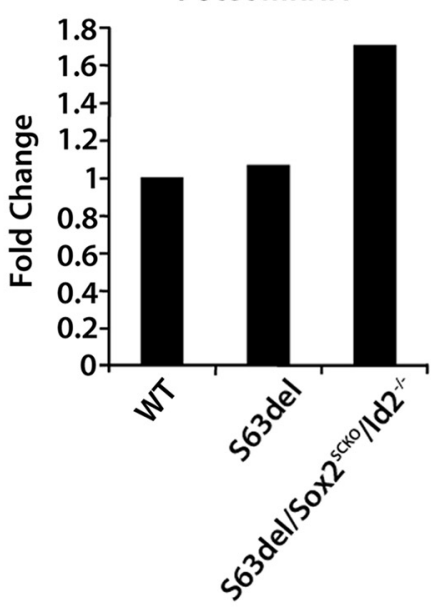

C

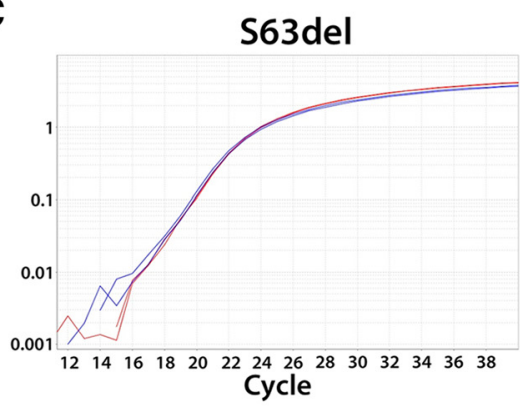

E
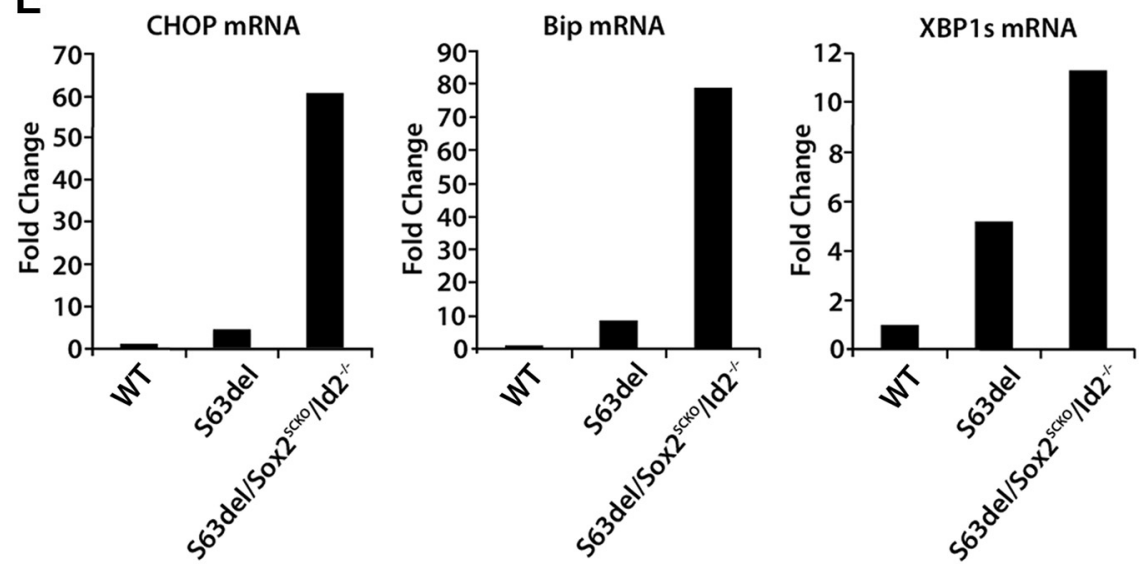

Figure 9. Ablation of Sox 2 and Id 2 increases P0 expression and exacerbates the UPR in S63del nerves. $A, q R T-P C R$ for total P0 mRNA on P18 -P21 sciatic nerves from WT control, S63del, and S63del/Sox2 $2^{\text {SCK0 }} / / \mathrm{d} 2^{-1-}$ mice. $\boldsymbol{B}-\boldsymbol{D}$, Allelic discrimination assay on RNA extracts from sciatic nerve of control, S63del, and S63del/Sox $2^{\mathrm{SCKO}} / \mathrm{ld} 2^{-1-}$ mice. Only the WT transcript is amplified in WT

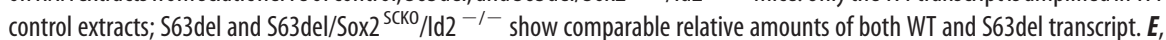
qRT-PCR for CHOP, Bip, and spliced Xbp1. All analyzed UPR factors are strongly upregulated in S63del/Sox $2^{\mathrm{SCKO}} / \mathrm{ld} 2^{-1-}$ compared with S63del, suggesting exacerbation of the ER stress. $n=2$ RT from independent pools of three sciatic nerves each.

proteins. This allows the cell to survive chronic stress, albeit at the expense of reduced myelination. Importantly, this latter characteristic is not totally unique to Schwann cells: chondrocytes carrying a nonsense mutation in the collagen 10 gene that induces a UPR are capable of limiting their differentiation and mutant collagen production, preserving cell viability (Tsang et al., 2007).

Negative regulators of myelination control Schwann-cellautonomous and -nonautonomous protective mechanisms in response to nerve insults

Our results are consistent with, and yet different from, what was observed in PMP22-C3 mice, which overexpress PMP22, par- tially recapitulating CMT1A. In these mice, ablation of c-Jun from Schwann cells led to a progressive loss of sensory axons and worsening of some behavioral and neurophysiological deficits (Hantke et al., 2014). Therefore, it appears that, in PMP22-overexpressing mice, as after nerve injury, activation of c-Jun in Schwann cells underlies a neuron-supportive mechanism, probably relying on positive trophic signals from the Schwann cells to the neurons (Arthur-Farraj et al., 2012; Fontana et al., 2012; Hantke et al., 2014). Instead, in S63del mice, the activation of Sox 2 and Id 2 appears to limit Schwann cell dysmyelination. The main reason for this difference may rely on the fact that, whereas in vivo ablation of Sox 2 and Id2 results in a transient hypermyelination, ablation of c-Jun does not increase myelination (Jessen and Mirsky, 2016). Conversely, c-Jun is crucial for myelin gene downregulation and activation of autophagy for myelin breakdown after injury (Parkinson et al., 2008; Gomez-Sanchez et al., 2015), processes in which Sox 2 does not appear to be involved (D.B. Parkinson, personal communication). Whether Id2 has a role in the events after nerve injury remains to be established. It is intriguing, however, that c-Jun is also activated in P0S63del and P0R98C mice (Saporta et al., 2012; D'Antonio et al., 2013) and that Sox 2 and Id2 expression is sustained in several PMP22 mutants (Giambonini-Brugnoli et al., 2005; Fledrich et al., 2014), suggesting that the activation of negative regulators of myelination in Schwann cells after nerve insult is part of a complex network aimed at protecting both Schwann cells and neurons.

\section{Conclusions}

Schwann cells are endowed with remarkable plasticity. This hallmark is of particular importance after nerve injury or in demyelinating neuropathies. In these scenarios, Schwann cells activate programs that ultimately reshape their phenotype, favoring on one side axonal regeneration and support, mostly through c-Jun and the tumor suppressor Merlin (Jessen and Mirsky, 2016; Mindos et al., 2017), but also allowing them to limit mutant protein toxicity, as shown here, through the activation of Sox 2 and Id2. These observations may have profound therapeutic relevance. Many cells, such as oligodendrocytes, do not possess the ability to regulate their differentiation status and, when faced with challenges such as the accumulation of misfolded proteins, undergo extensive apoptosis (Gow et al., 1998). The activation or amplification of signals aimed at limiting terminal differentiation in cells that are naturally incapable of triggering them may potentially provide important benefits. 


\section{References}

Arthur-Farraj PJ, Latouche M, Wilton DK, Quintes S, Chabrol E, Banerjee A, Woodhoo A, Jenkins B, Rahman M, Turmaine M, Wicher GK, Mitter R, Greensmith L, Behrens A, Raivich G, Mirsky R, Jessen KR (2012) c-jun reprograms schwann cells of injured nerves to generate a repair cell essential for regeneration. Neuron 75:633-647. CrossRef Medline

Bartesaghi L, Arnaud Gouttenoire E, Prunotto A, Medard JJ, Bergmann S, Chrast R (2015) Sox4 participates in the modulation of schwann cell myelination. Eur J Neurosci 42:1788-1796. CrossRef Medline

Britsch S, Goerich DE, Riethmacher D, Peirano RI, Rossner M, Nave KA, Birchmeier C, Wegner M (2001) The transcription factor Sox10 is a key regulator of peripheral glial development. Genes Dev 15:66-78. CrossRef Medline

Chen XS, Zhang YH, Cai QY, Yao ZX (2012) ID2: a negative transcription factor regulating oligodendroglia differentiation. J Neurosci Res 90:925932. CrossRef Medline

Chen Y, Wu H, Wang S, Koito H, Li J, Ye F, Hoang J, Escobar SS, Gow A, Arnett HA, Trapp BD, Karandikar NJ, Hsieh J, Lu QR (2009) The oligodendrocyte-specific G protein-coupled receptor GPR17 is a cellintrinsic timer of myelination. Nat Neurosci 12:1398-1406. CrossRef Medline

D’Antonio M, Droggiti A, Feltri ML, Roes J, Wrabetz L, Mirsky R, Jessen KR (2006) TGFbeta type II receptor signaling controls schwann cell death and proliferation in developing nerves. J Neurosci 26:8417-8427. CrossRef Medline

D'Antonio M, Musner N, Scapin C, Ungaro D, Del Carro U, Ron D, Feltri ML, Wrabetz L (2013) Resetting translational homeostasis restores myelination in Charcot-Marie-Tooth disease type 1B mice. J Exp Med 210: 821-838. CrossRef Medline

Dull T, Zufferey R, Kelly M, Mandel RJ, Nguyen M, Trono D, Naldini L (1998) A third-generation lentivirus vector with a conditional packaging system. J Virol 72:8463-8471. Medline

Feltri ML, Scherer SS, Wrabetz L, Kamholz J, Shy ME (1992) Mitogenexpanded schwann cells retain the capacity to myelinate regenerating axons after transplantation into rat sciatic nerve. Proc Natl Acad Sci U S A 89:8827-8831. CrossRef Medline

Feltri ML, D’Antonio M, Quattrini A, Numerato R, Arona M, Previtali S, Chiu SY, Messing A, Wrabetz L (1999) A novel P0 glycoprotein transgene activates expression of lacZ in myelin-forming schwann cells. Eur J Neurosci 11:1577-1586. CrossRef Medline

Feltri ML, Poitelon Y, Previtali SC (2016) How schwann cells sort axons: new concepts. Neuroscientist 22:252-265. CrossRef Medline

Fledrich R, Stassart RM, Klink A, Rasch LM, Prukop T, Haag L, Czesnik D, Kungl T, Abdelaal TA, Keric N, Stadelmann C, Brück W, Nave KA, Sereda MW (2014) Soluble neuregulin-1 modulates disease pathogenesis in rodent models of Charcot-Marie-Tooth disease 1A. Nat Med 20:10551061. CrossRef Medline

Follenzi A, Sabatino G, Lombardo A, Boccaccio C, Naldini L (2002) Efficient gene delivery and targeted expression to hepatocytes in vivo by improved lentiviral vectors. Hum Gene Ther 13:243-260. CrossRef Medline

Fontana X, Hristova M, Da Costa C, Patodia S, Thei L, Makwana M, SpencerDene B, Latouche M, Mirsky R, Jessen KR, Klein R, Raivich G, Behrens A (2012) c-jun in schwann cells promotes axonal regeneration and motoneuron survival via paracrine signaling. J Cell Biol 198:127-141. CrossRef Medline

Fratta P, Saveri P, Zambroni D, Ferri C, Tinelli E, Messing A, D'Antonio M, Feltri ML, Wrabetz L (2011) P0S63del impedes the arrival of wild-type P0 glycoprotein to myelin in CMT1B mice. Hum Mol Genet 20:20812090. CrossRef Medline

Ghislain J, Desmarquet-Trin-Dinh C, Gilardi-Hebenstreit P, Charnay P, Frain M (2003) Neural crest patterning: autoregulatory and crestspecific elements co-operate for Krox20 transcriptional control. Development 130:941-953. CrossRef Medline

Giambonini-Brugnoli G, Buchstaller J, Sommer L, Suter U, Mantei N (2005) Distinct disease mechanisms in peripheral neuropathies due to altered peripheral myelin protein 22 gene dosage or a Pmp22 point mutation. Neurobiol Dis 18:656-668. CrossRef Medline

Gomez-Sanchez JA, Carty L, Iruarrizaga-Lejarreta M, Palomo-Irigoyen M, Varela-Rey M, Griffith M, Hantke J, Macias-Camara N, Azkargorta M, Aurrekoetxea I, De Juan VG, Jefferies HB, Aspichueta P, Elortza F, Aransay AM, Martínez-Chantar ML, Baas F, Mato JM, Mirsky R, Woodhoo A, et al. (2015) Schwann cell autophagy, myelinophagy, initiates myelin clearance from injured nerves. J Cell Biol 210:153-168. CrossRef Medline Gow A, Southwood CM, Lazzarini RA (1998) Disrupted proteolipid protein trafficking results in oligodendrocyte apoptosis in an animal model of pelizaeus-merzbacher disease. J Cell Biol 140:925-934. CrossRef Medline

Hantke J, Carty L, Wagstaff LJ, Turmaine M, Wilton DK, Quintes S, Koltzenburg M, Baas F, Mirsky R, Jessen KR (2014) c-jun activation in schwann cells protects against loss of sensory axons in inherited neuropathy. Brain 137:2922-2937. CrossRef Medline

Jaegle M, Mandemakers W, Broos L, Zwart R, Karis A, Visser P, Grosveld F, Meijer D (1996) The POU factor oct-6 and schwann cell differentiation. Science 273:507-510. CrossRef Medline

Jessen KR, Mirsky R (2005) The origin and development of glial cells in peripheral nerves. Nat Rev Neurosci 6:671-682. CrossRef Medline

Jessen KR, Mirsky R (2008) Negative regulation of myelination: relevance for development, injury, and demyelinating disease. Glia 56:1552-1565. CrossRef Medline

Jessen KR, Mirsky R (2016) The repair schwann cell and its function in regenerating nerves. J Physiol 594:3521-3531. CrossRef Medline

Le N, Nagarajan R, Wang JY, Araki T, Schmidt RE, Milbrandt J (2005) Analysis of congenital hypomyelinating Egr2Lo/Lo nerves identifies Sox2 as an inhibitor of schwann cell differentiation and myelination. Proc Natl Acad Sci U S A 102:2596-2601. CrossRef Medline

Mager GM, Ward RM, Srinivasan R, Jang SW, Wrabetz L, Svaren J (2008) Active gene repression by the Egr2.NAB complex during peripheral nerve myelination. J Biol Chem 283:18187-18197. CrossRef Medline

Miller LJ, Patzkó A, Lewis RA, Shy ME (2012) Phenotypic presentation of the Ser63Del MPZ mutation. J Peripher Nerv Syst 17:197-200. CrossRef Medline

Mindos T, Dun XP, North K, Doddrell RD, Schulz A, Edwards P, Russell J, Gray B, Roberts SL, Shivane A, Mortimer G, Pirie M, Zhang N, Pan D, Morrison H, Parkinson DB (2017) Merlin controls the repair capacity of schwann cells after injury by regulating Hippo/YAP activity. J Cell Biol 216:495-510. CrossRef Medline

Occhi S, Zambroni D, Del Carro U, Amadio S, Sirkowski EE, Scherer SS, Campbell KP, Moore SA, Chen ZL, Strickland S, Di Muzio A, Uncini A, Wrabetz L, Feltri ML (2005) Both laminin and schwann cell dystroglycan are necessary for proper clustering of sodium channels at nodes of ranvier. J Neurosci 25:9418-9427. CrossRef Medline

Parkinson DB, Bhaskaran A, Droggiti A, Dickinson S, D’Antonio M, Mirsky R, Jessen KR (2004) Krox-20 inhibits jun-NH2-terminal kinase/c-jun to control schwann cell proliferation and death. J Cell Biol 164:385-394. CrossRef Medline

Parkinson DB, Bhaskaran A, Arthur-Farraj P, Noon LA, Woodhoo A, Lloyd AC, Feltri ML, Wrabetz L, Behrens A, Mirsky R, Jessen KR (2008) c-jun is a negative regulator of myelination. J Cell Biol 181:625-637. CrossRef Medline

Patzkó A, Bai Y, Saporta MA, Katona I, Wu X, Vizzuso D, Feltri ML, Wang S, Dillon LM, Kamholz J, Kirschner D, Sarkar FH, Wrabetz L, Shy ME (2012) Curcumin derivatives promote schwann cell differentiation and improve neuropathy in R98C CMT1B mice. Brain 135:3551-3566. CrossRef Medline

Pennuto M, Tinelli E, Malaguti M, Del Carro U, D'Antonio M, Ron D, Quattrini A, Feltri ML, Wrabetz L (2008) Ablation of the UPR-mediator $\mathrm{CHOP}$ restores motor function and reduces demyelination in CharcotMarie-Tooth 1B mice. Neuron 57:393-405. CrossRef Medline

Porrello E, Rivellini C, Dina G, Triolo D, Del Carro U, Ungaro D, Panattoni M, Feltri ML, Wrabetz L, Pardi R, Quattrini A, Previtali SC (2014) Jab1 regulates schwann cell proliferation and axonal sorting through p27. J Exp Med 211:29-43. CrossRef Medline

Prasad MK, Reed X, Gorkin DU, Cronin JC, McAdow AR, Chain K, Hodonsky CJ, Jones EA, Svaren J, Antonellis A, Johnson SL, Loftus SK, Pavan WJ, McCallion AS (2011) SOX10 directly modulates ERBB3 transcription via an intronic neural crest enhancer. BMC Dev Biol 11:40. CrossRef Medline

Roberts SL, Dun XP, Doddrell RDS, Mindos T, Drake LK, Onaitis MW, Florio F, Quattrini A, Lloyd AC, D'Antonio M, Parkinson DB (2017) Sox2 expression in schwann cells inhibits myelination in vivo and induces influx of macrophages to the nerve. Development 144:3114-3125. CrossRef Medline

Saporta MA, Shy BR, Patzkó A, Bai Y, Pennuto M, Ferri C, Tinelli E, Saveri P, Kirschner D, Crowther M, Southwood C, Wu X, Gow A, Feltri ML, Wra- 
betz L, Shy ME (2012) MpzR98C arrests schwann cell development in a mouse model of early-onset Charcot-Marie-Tooth disease type 1B. Brain 135:2032-2047. CrossRef Medline

Stewart HJ, Zoidl G, Rossner M, Brennan A, Zoidl C, Nave KA, Mirsky R, Jessen KR (1997) Helix-loop-helix proteins in schwann cells: a study of regulation and subcellular localization of ids, REB, and E12/47 during embryonic and postnatal development. J Neurosci Res 50:684-701. CrossRef Medline

Stolt CC, Wegner M (2016) Schwann cells and their transcriptional network: evolution of key regulators of peripheral myelination. Brain Res 1641:101-110. CrossRef Medline

Svaren J, Meijer D (2008) The molecular machinery of myelin gene transcription in schwann cells. Glia 56:1541-1551. CrossRef Medline

Taranova OV, Magness ST, Fagan BM, Wu Y, Surzenko N, Hutton SR, Pevny LH (2006) SOX2 is a dose-dependent regulator of retinal neural progenitor competence. Genes Dev 20:1187-1202. CrossRef Medline

Topilko P, Schneider-Maunoury S, Levi G, Baron-Van Evercooren A, Chennoufi AB, Seitanidou T, Babinet C, Charnay P (1994) Krox-20 controls myelination in the peripheral nervous system. Nature 371:796-799. CrossRef Medline

Tsang KY, Chan D, Cheslett D, Chan WC, So CL, Melhado IG, Chan TW, Kwan KM, Hunziker EB, Yamada Y, Bateman JF, Cheung KM, Cheah KS (2007) Surviving endoplasmic reticulum stress is coupled to altered chondrocyte differentiation and function. PLoS Biol 5:e44. CrossRef Medline

Valentijn LJ, Baas F, Wolterman RA, Hoogendijk JE, van den Bosch NH, Zorn I, Gabreëls-Festen AW, de Visser M, Bolhuis PA (1992) Identical point mutations of PMP-22 in trembler-J mouse and Charcot-Marie-Tooth disease type 1A. Nat Genet 2:288-291. CrossRef Medline

Verheijen MH, Camargo N, Verdier V, Nadra K, de Preux Charles AS, Médard JJ, Luoma A, Crowther M, Inouye H, Shimano H, Chen S, Brouwers JF, Helms JB, Feltri ML, Wrabetz L, Kirschner D, Chrast R, Smit AB
(2009) SCAP is required for timely and proper myelin membrane synthesis. Proc Natl Acad Sci U S A 106:21383-21388. CrossRef Medline

Volpi VG, Touvier T, D’Antonio M (2017) Endoplasmic reticulum protein quality control failure in myelin disorders. Front Mol Neurosci 9:162. CrossRef Medline

Walter P, Ron D (2011) The unfolded protein response: from stress pathway to homeostatic regulation. Science 334:1081-1086. CrossRef Medline

Warner LE, Hilz MJ, Appel SH, Killian JM, Kolodry EH, Karpati G, Carpenter S, Watters GV, Wheeler C, Witt D, Bodell A, Nelis E, Van Broeckhoven C, Lupski JR (1996) Clinical phenotypes of different MPZ (P0) mutations may include Charcot-Marie-Tooth type 1B, Dejerine-Sottas, and congenital hypomyelination. Neuron 17:451-460. CrossRef Medline

Woodhoo A, Alonso MB, Droggiti A, Turmaine M, D'Antonio M, Parkinson DB, Wilton DK, Al-Shawi R, Simons P, Shen J, Guillemot F, Radtke F, Meijer D, Feltri ML, Wrabetz L, Mirsky R, Jessen KR (2009) Notch controls embryonic schwann cell differentiation, postnatal myelination and adult plasticity. Nat Neurosci 12:839-847. CrossRef Medline

Wrabetz L, Feltri ML, Quattrini A, Imperiale D, Previtali S, D’Antonio M, Martini R, Yin X, Trapp BD, Zhou L, Chiu SY, Messing A (2000) P(0) glycoprotein overexpression causes congenital hypomyelination of peripheral nerves. J Cell Biol 148:1021-1034. CrossRef Medline

Wrabetz L, D'Antonio M, Pennuto M, Dati G, Tinelli E, Fratta P, Previtali S, Imperiale D, Zielasek J, Toyka K, Avila RL, Kirschner DA, Messing A, Feltri ML, Quattrini A (2006) Different intracellular pathomechanisms produce diverse myelin protein zero neuropathies in transgenic mice. J Neurosci 26:2358-2368. CrossRef Medline

Yokota Y, Mansouri A, Mori S, Sugawara S, Adachi S, Nishikawa S, Gruss P (1999) Development of peripheral lymphoid organs and natural killer cells depends on the helix-loop-helix inhibitor Id2. Nature 397:702-706. CrossRef Medline

Yokota Y, Mori S, Narumi O, Kitajima K (2001) In vivo function of a differentiation inhibitor, Id2. IUBMB Life 51:207-214. CrossRef Medline 